\title{
Who Supported the Early Muslim Brotherhood?
}

\author{
Neil Ketchley, Steven Brooke and Brynjar Lia*
}

September 28, 2021

\begin{abstract}
Scholarship on political Islam suggests that support for early Islamist movements came from literate merchants, government officials, and professionals who lacked political representation. We test these claims with a unique tranche of microlevel data drawn from a Muslim Brotherhood petition campaign in interwar Egypt. Matching the occupations of over 2,500 Brotherhood supporters to contemporaneous census data, we show that Egyptians employed in commerce, public administration, and the professions were more likely to sign the movements petitions. The movements supporters were also overwhelmingly literate. Contrary to expectations, the early Brotherhood also attracted support from Egyptians employed in agriculture, albeit less than we would expect given the prevalence of agrarian workers in the population. A case study tracing Muslim Brotherhood branch formation and petition activism in a Nile Delta village illustrates how literate, socially mobile agrarian families were key to the propagation of the movement in rural areas.
\end{abstract}

Keywords - Political Islam; Muslim Brotherhood; Egypt

*Neil Ketchley (neil.ketchley@politics.ox.ac.uk) is Associate Professor in Politics in the Department of Politics and International Relations and Fellow of St Antony's College, University of Oxford. Steven Brooke (sbrooke@wisc.edu) is Assistant Professor in Political Science in the Department of Political Science at the University of Wisconsin - Madison. Brynjar Lia (brynjar.lia@ikos.uio.no) is Professor of Middle East Studies in the Department of Culture Studies and Oriental Languages, University of Oslo. We are grateful for feedback from Nathan Brown, Ken Cuno, Mohamed Saleh, and John Sidel, for constructive comments from two anonymous reviewers and the editors, to Gabriel Koehler-Derrick for sharing data, and to Ahmad Atif for research assistance. This research was funded by the University of Oslo and the Office of the Vice Chancellor for Research and Graduate Education at the University of Wisconsin-Madison with funding from the Wisconsin Alumni Research Foundation. 


\section{Introduction}

Since their emergence in the early twentieth century, mass participation Islamist movements have gone on to become key actors in the politics of the Middle East and beyond (Ayoob, 2009; Hafez, 2003; Moaddel, 2005; Wickham, 2002; Wiktorowicz, 2004). In this paper, we return to the first instances of Islamist mobilization to examine the social backgrounds of thousands of early supporters of political Islam. In doing so, we build on a rich case literature that keys support for the first Islamist movements to socially mobile, literate Muslims employed in commerce, public administration, and the professions (see e.g. Ayubi 1991; Davis 1984; Lia 1998; Mitchell 1993; Munson 2001; Masoud 2014). According to these studies, Islamist activism served as a vehicle for political aspirations and social advancement. A corollary of this claim is that early Islamist movements attracted little support from the nascent working class and those employed in the agrarian economy. While these arguments are widespread in the literature on political Islam, they are primarily derived from small samples of prominent activists and leaders. This naturally raises questions about how well these claims generalize to rank-and-file members and ordinary supporters.

To conduct our study, we use novel, micro-level data that captures the social backgrounds of thousands of supporters of the early Egyptian Muslim Brotherhood. Following its founding in 1928, the Brotherhood would go on to become one of the largest and most influential Islamist movements in the world (Lia, 1998; Mitchell, 1993). We focus on a pivotal moment in the movement's early growth: in 1941, Muslim Brotherhood branches from across Egypt sent petitions to the Egyptian government protesting the arrest of the movement's leadership by the wartime authorities. Uniquely, these petitions record the names and occupations, as well as the literacy status, of over 2,500 individuals. Matching this source material to newly digitized, contemporaneous census records presents the first opportunity to systematically compare a large sample of early supporters of political Islam to the underlying population from which they are drawn.

As we show, the rate at which Muslim Brotherhood supporters signed their names 
to these petitions, as opposed to illiterate supporters who used stamps, greatly exceeds the literacy rate in the districts that signers came from. This lends weight to the claim that the early Brotherhood was more likely to attract support from literate Muslims. Most importantly, after accounting for their prevalence in the population, Egyptians employed in commerce, public administration, and the professions were significantly overrepresented among the signatories. Egyptians working in agriculture and manufacturing were statistically less likely to sign the Brotherhood's petitions; however, in terms of raw numbers, the Brotherhood did manage to attract more support from agrarian workers than we might expect given claims made in the case literature. To expand on the statistical findings, we conduct a case study of local families in Gamgara al-Gadida, a rural village in Qalyubiyya governorate in the Nile Delta that furnished one of the petitions. By triangulating lists of founding officers of the Gamgara al-Gadida branch reported in Brotherhood periodicals, high-resolution maps detailing local landholdings, and other archival sources, we are able to reconstruct the social backgrounds of those early Muslim Brotherhood members who signed this village's petition. As the qualitative case details show, the Muslim Brotherhood appears to have been especially adept at channeling the aspirations of Egypt's literate yet politically underrepresented rural middle class including small farmers and the relatives of agricultural workers — into consequential social movement activism.

\section{Social sources of early political Islam}

The decades following the First World War saw mass participation Islamist movements emerge in the Indonesian Archipelago (Noer, 1973; Shiraishi, 1990), Central Asia (Khalid, 1999), the Indian subcontinent (Minault, 1982; Reetz, 2006), and the Middle East and North Africa (Lia, 1998; Brooke and Ketchley, 2018; Masoud, 2014). One of the most consequential movements to be established during this period was the Egyptian Muslim Brotherhood, who would go on to claim several hundred thousand members and establish an organizational presence in most Muslim-majority countries (Wickham, 2013). A key 
topic for scholarship has been to explain the sudden growth of the Muslim Brotherhood, and in particular, its initial social sources of support (Masoud, 2014). In what follows, we review that literature, identifying the empirical state of the art, as well as considering why one or another social group was more or less likely to support the Brotherhood.

\subsection{Who supported the early Muslim Brotherhood?}

Much of what we know about the social backgrounds of early Muslim Brotherhood supporters is derived from biographies of prominent members and the movement's leadership. Mitchell (1993) begins the genre by analyzing the appellations of 112 delegates to a Muslim Brotherhood conference held in 1935. As he notes $(1993,329)$, most of the delegates were "effendis" — members of Egypt's literate, lower middle classes. Mitchell's book-length account of the Brotherhood is also noteworthy for being the first to leverage repression to generate samples of movement supporters. In an analysis of several dozen Muslim Brothers arrested in the 1950s, Mitchell discerns an "urban middle class effendi predominance among the activist membership." We obtain a more precise description from Ayubi (1980, 493), who analyzes trial data and "wanted" lists of several hundred Brothers published by the Egyptian government in the 1950s. As he observes, "the Muslim Brothers who were brought to trial were mainly civil servants, teachers, whitecollar workers, small merchants, businessmen, and students." Davis (1984, 142-143) reports a similar pattern in his analysis of 11 Muslim Brotherhood leaders active in the 1930s and trial data of 701 Muslim Brothers arrested in 1954 and 1965. Munson (2001, 492) who draws on U.S. State Department reports of 179 Muslim Brothers arrested in 1954, also finds that government bureaucrats, professionals, and small business owners were especially prevalent amongst the movement's membership.

When explaining the prominence of these occupational groups, a recurring claim is that support for early political Islam traces back to a "revolt of the petite bourgeoisie" (Fischer, 1982). In this telling, the first Islamists - "the petty clerks and functionaries of the overswollen bureaucracy ... and the small businessman" (Wendell, 1978, 5) — were increasingly politically conscious, but otherwise overlooked by a political elite dominated 
by aristocratic notables and large landowners. ${ }^{1}$ As Harnett and Saleh (2021) document, in the decades leading up to the emergence of the Brotherhood, professionals, bureaucrats, and those employed in commerce were almost completely absent from Egypt's parliament and political institutions. Figure 1 shows the occupations of MPs elected to the Lower House of the Egyptian Parliament in 1936, shortly after the founding of the Brotherhood (cited in Subhi, 1939, 175-190). The trend is clear: notables, former ministers, and landowners dominate, while merchants and government employees are vanishingly rare. Lawyers are well-represented; however, teachers, doctors and other professionals barely feature. Egypt's largest parliamentary movement at this time, the Wafd, embodied this tendency, showing little appetite for expanding its membership beyond a small group of notables. In consequence, the Wafd often appeared to be little more than a "broad banner hovering over a crowd which it had no interest in organizing" (Issa cited in Abdalla, $2008,21)$. This, at a time of increasing mobilization and associational activities that saw the emergence of new extra-parliamentary movements and religious societies that were increasingly critical of the Wafd's political leadership and their failure to end British colonial rule (see especially Jankowski, 1975; Gershoni and Jankowski, 2009). Against this backdrop, it is argued, new social movements in the interwar period looked to mobilize those "disenchanted elements of the middle classes" (Abdalla, 2008, 21) who sought a political voice at a time of profound socio-economic transformation and national political consciousness (see Lia 1998; Tripp 1984).

A corollary argument is that early supporters of the Muslim Brotherhood were also disproportionately literate (Ayoob, 2009; Moaddel, 2005; Kalmbach, 2020). Brooke and Ketchley (2018) provide systematic evidence for this tendency, showing that the Muslim Brotherhood was initially more likely to establish branches in areas with higher literacy rates (see also Masoud, 2014). In making sense of this association, scholars often invoke

\footnotetext{
${ }^{1}$ As Ayubi $(1994,70)$ catalogs, Egyptian notables were a landowning-bureaucratic elite, many of whom owed their status to being military officers and tax farmers in the period prior to the British occupation. Under that occupation, these notables became key intermediaries between the colonial government and Egypts provincial authorities, while also expanding their economic power through new initiatives tied to agro-capitalism and nascent industrialization.
} 
Figure 1: Occupational backgrounds of Egyptian MPs, 1936

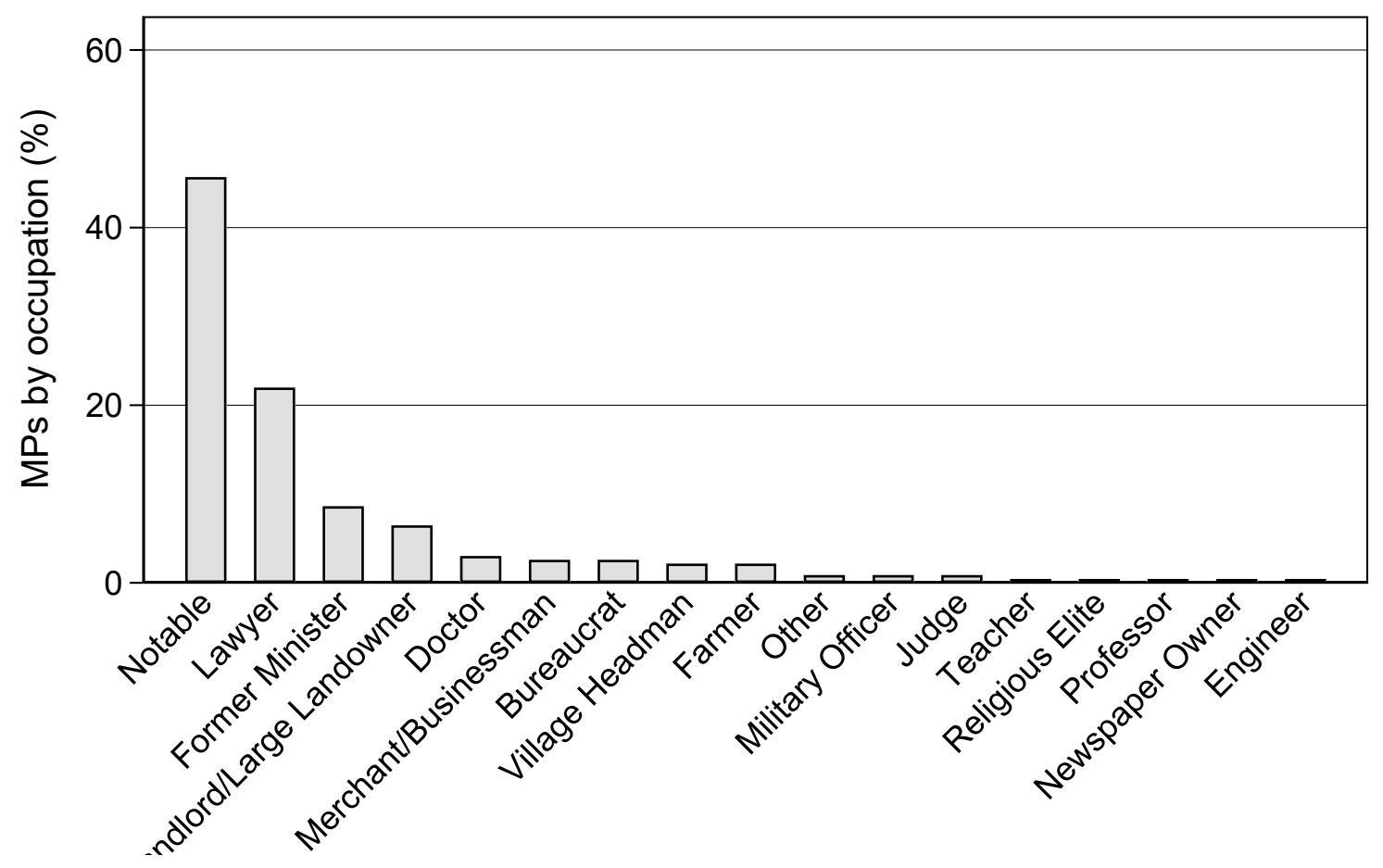

a mechanism that parallels Anderson's (2006 (1983) classic argument for the origins of nationalist consciousness. Summarized, rising literacy rates and new opportunities for social advancement developed coeval to the expansion of state administrations and national economies. This, in turn, produced novel forms of political imagination and activism that mobilized in opposition to established hierarchies and European colonial encroachment. ${ }^{2}$ In the Egyptian context, this process saw literate, socially mobile Muslims, who otherwise lacked representation in the country's elitist, patronclient dominated political system, emerge as a natural constituency for early Islamist movements (Masoud, 2014).

A related claim is that the early Muslim Brotherhood drew little support from those employed in the agrarian economy (see Ayubi, 1980, 493). ${ }^{3}$ As Brown (1990b, 163-164)

${ }^{2}$ Of course, Anderson argued that the new "imagined communities" that emerged as a consequence of these processes were inherently secular and republican. This, despite Anderson anchoring his argument in episodes of nationalist mobilization in southeast Asia that drew considerable support and inspiration from new forms of Islamist activism (see Sidel 2021; Fogg 2019).

${ }^{3}$ Mitchell, for example, claims that rural Egypt was never more than a "backdrop" for the urban activists 
notes,

The Ikhwan [Brotherhood] was successful in forming village chapters in several areas of Egypt. Members of these branches, however, were generally not peasants but school teachers and shop keepers ... The [Brotherhood] displayed little interest in agrarian issues ... there is little evidence that the organisation could inspire the peasants to support them actively.

Kupferschmidt $(1982,166)$ similarly notes the Brotherhood's lack of support from those employed in the agrarian economy. However, he attributes this lack of affinity less to dissimilar economic and political interests than to the prevalence of illiteracy in the countryside and dominant folk forms of religious practice antagonistic to the Brotherhood's "scripturalist" interpretation of Islam. Alongside the Brotherhood's relative failure to recruit agrarian workers, scholars also note a dearth of support from Egypt's nascent working class. As Beinin and Lockman (1998, ch. 11) catalog, despite some limited early initiatives, it was not until the post-Second World War period that the Muslim Brotherhood began to engage with workers' issues — and only then in an attempt to counter the activities of communists.

While plausible, these arguments also raise questions. As noted above, much of what we know about early support for political Islam comes from the biographies of prominent members, many of whom only became active several decades after the Brotherhood emerged. Moreover, a reliance on trial and arrest data reported in print media inevitably captures only the most newsworthy individuals, rather than those ordinary supporters who comprise the bulk of any movement. We might also expect that samples of leading members who attend movement conferences, or who are arrested for engaging in clandestine and illegal activities, may systematically differ from the modal member or supporter. In other words, it is important to assess whether the occupational backgrounds and socioeconomic status prevalent among particularly prominent Muslim Brothers was shared by the movement's rank-and-file supporters.

Crucially, neither do the aforementioned studies compare the characteristics of Muslim Brotherhood supporters against population baselines. ${ }^{4}$ In consequence, we do not that powered the movement $(1993,329)$

${ }^{4}$ Exceptions are Brooke and Ketchley (2018) and Masoud (2014). However, those analyses can only 
know if the prominence of certain socioeconomic profiles among the Muslim Brothers' supporters simply reflects and reproduces the prevalence of those profiles in the underlying population. ${ }^{5}$ As Ketchley and Biggs (2017) argue, failing to make such comparisons can lead to spurious inferences when analyzing the social bases of Islamist support. As they show, the popular claim that engineers are over-represented amongst more contemporary Islamist movements likely does not hold after accounting for the very large number of graduates from that discipline. Insofar as studies on the rise of political Islam link the appeal of Islamist activism to particular occupations and individual-level characteristics (and not others), this is a notable shortcoming of the literature.

\section{Muslim Brotherhood petitions}

In 1928, Hasan al-Banna, a public school teacher and recent graduate, founded the Muslim Brotherhood in the Suez Canal town of Ismailiyya. Al-Banna's religious message, tireless organizing, and adoption of a modern repertoire of contention, rapidly grew the movement into a national political force (Lia, 2015). Within a decade, hundreds of Muslim Brotherhood branches had been established across the country (Brooke and Ketchley, 2018). In urban quarters and rural towns, Brotherhood activists spoke in mosques, paraded publicly, raised money for various causes, established social services, and generally worked to implement al-Banna's message of Islamic revival.

As the Muslim Brotherhood grew into a national organization, Hasan al-Banna began to increasingly intervene into the politics of the day. In speeches, missives to officials, and articles in the movement's various media outlets, al-Banna supported the Arab Revolt in Palestine, inveighed against French abuses in North Africa, and criticized both British suzerainty in Egypt, as well as Egypt's political elite who he portrayed as accommodating

capture the aggregate characteristics of the places where the Brotherhood established an organizational presence, rather than the characteristics of the movement's individual supporters.

${ }^{5}$ Kupferschmidt $(1982,159)$ is a partial exception here, noting that Egyptians employed in the agrarian economy are "strikingly under-represented [in the Muslim Brotherhood] ... although forming a majority of the population." 
it (see Awaisi, 1998; Gershoni, 1986; Gershoni and Jankowski, 2009). With the onset of the Second World War and the imposition of censorship and bans on political activities, al-Banna's increasing notoriety and expanding movement inevitably brought him to the attention of the wartime authorities.

In May 1941, this conflict broke into the open. Following a pro-Axis coup in Britishcontrolled Iraq, and amid rumors of similar plottings in Cairo, the Ministry of Education ordered that al-Banna be transferred from the capital to the Upper Egyptian governorate of Qena, nearly 500 kilometers away. As regional tensions cooled he was allowed to return from this internal exile to the capital a few months later, on the condition that he stay out of politics (Mitchell, 1993, 21). But at a mass meeting held the following month in the Nile Delta, al-Banna again publicly criticized the Egyptian government, as well as the British occupation, and was promptly arrested. Also taken into custody was the movement's deputy leader, Ahmed al-Sukkari, and the Brotherhood's general secretary, Abd al-Hakim Abdin (Lia, 1998, 264-265).

The arrest of the Brotherhood's national leadership prompted an unprecedented show of solidarity by the movement's membership and supporters. In the days following the arrests, Muslim Brotherhood branches from across Egypt registered their dissent by directly petitioning Egypt's authorities. In a report on the incident, the British Residency in Cairo recalled these petitions being "showered upon the king and prime minister" (Foreign Office, 1942, 3). Fearful that anger at the arrests could escalate into widespread street-level mobilization, the authorities capitulated and released the Brotherhood's leadership (Lia, 1998, 264-265). However, this demonstration of grassroots support for the Brotherhood marked a shift in relations between the movement and the political authorities. "From that time" Richard Mitchell tells us, "no government in Egypt avoided clashing with the Society of the Muslim Brothers" (1993, 23). 


\section{Empirical strategy}

These petitions provide an unprecedented, micro-level insight into the social sources of early Muslim Brotherhood support. The petitions themselves were (and presumably are still) stored in the Egyptian National Archives in Cairo in a folder labelled "The Petitions of the Muslim Brotherhood," alongside a number of other petitions sent by the movement between 1936 and $1947 .{ }^{6}$ Uniquely, a portion of the petitions sent in response to the arrests of the Brotherhood's leadership in 1941 also record signatories' names and occupations. Figure 2 is an example of one of these petitions, sent from the Muslim Brotherhood's branch in Gamgara al-Gadida, in Banha, Qalyubiyya governorate. Together, these petitions contain information for 2,515 individuals. The median petition contains 145 signatures; the maximum has 434. An analysis of signatories' names suggests that all of the signers were male.

In total, we analyze petitions sent from 15 Muslim Brotherhood branches. In the same folder, there are a number of other petitions from this period, but where information about signatories' occupations is either not recorded or not recoverable. We also suspect that a potentially large number of petitions were sent but not retained. While we cannot know the exact number of missing petitions, we can calculate an approximate upper bound of missingness using a comprehensive Muslim Brotherhood branch survey published in May 1940 (Brooke and Ketchley, 2018). That document contains a listing for 260 branches; if each of these sent a petition in 1941, then those we recovered from the archive would constitute six percent of all petitions sent.

This naturally raises questions around the representativeness of our signatories. We suspect that some branches sent petitions that were either discarded upon receipt or else did not survive the passage of time. These unobserved selection effects - first into the archive, and then into our sample — have important implications for how well our signatories represent the universe of Muslim Brotherhood supporters. While we cannot recover the logic behind why some petitions survived and others did not, we

${ }^{6}$ This folder and a host of other MB-related documents were found and photocopied by one of the authors (Lia) during archival research in Cairo in 1994-95. 


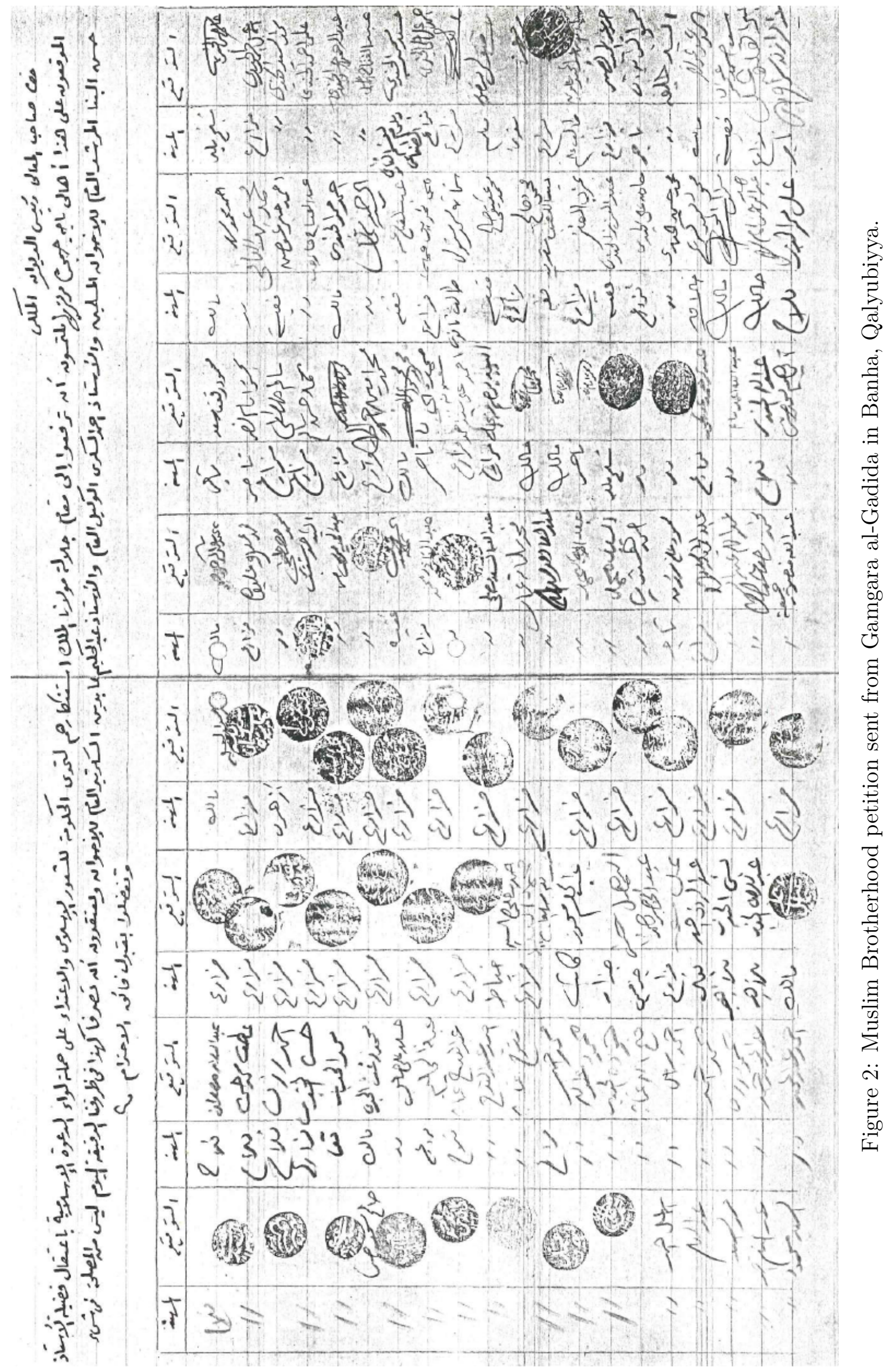


Figure 3: No petition vs. petition branches, 1940
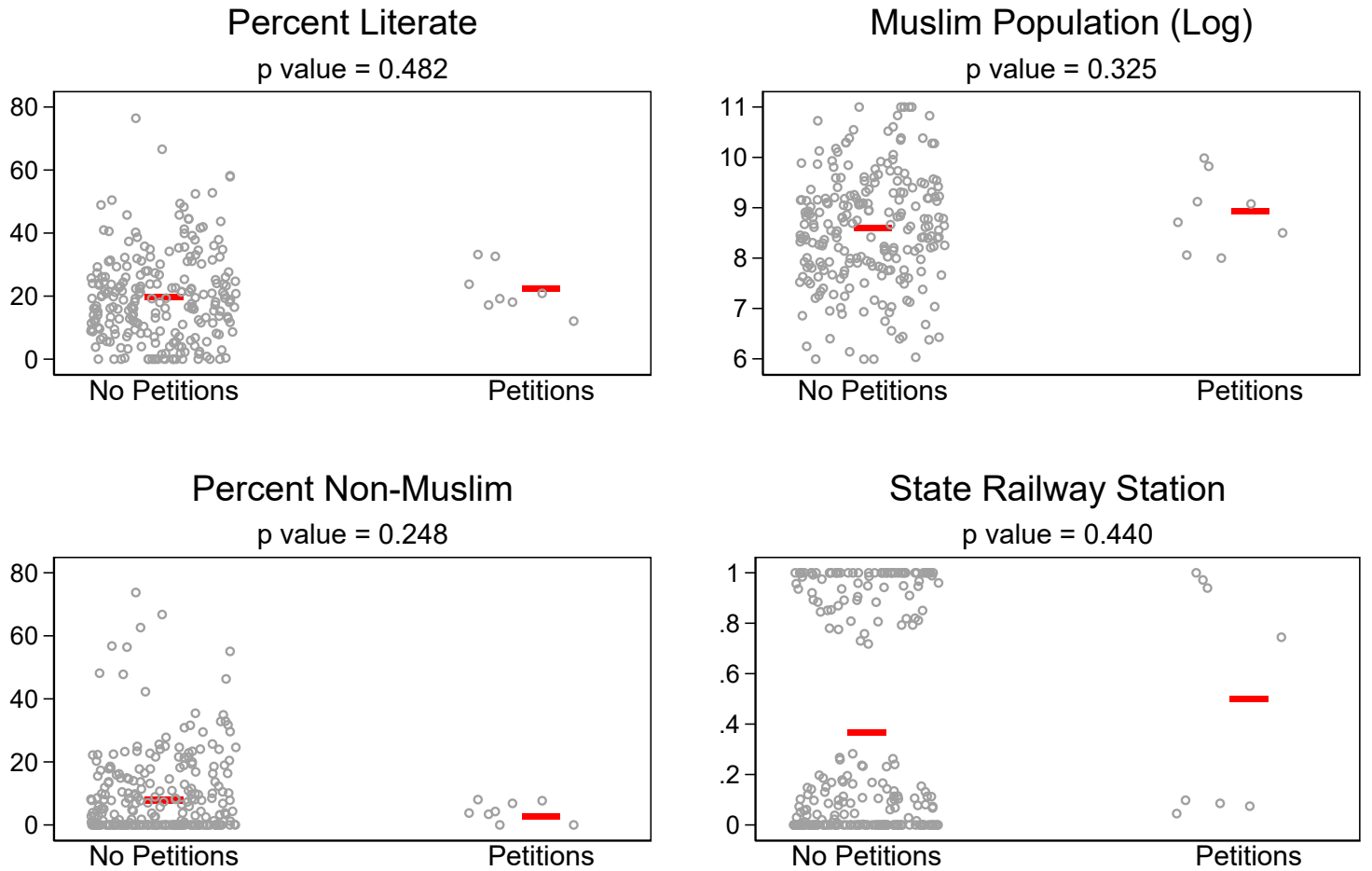

can test whether those branches for which a petition survives are significantly different from subdistricts that we know hosted a Muslim Brotherhood branch, but for which we have no petition. To do this, we draw on Brooke and Ketchley's (2018) analysis of Muslim Brotherhood branch formation in 1940, which identifies four key ecological factors that predict the presence of a Brotherhood branch: the size of a subdistrict's Muslim population, the literacy rate, the proportion of non-Muslims, and the presence of an Egyptian State Railway station. Using those four variables, Figure 3 tests the difference in means for petition and non-petition branches with point estimates located on their 95 percent confidence intervals. ${ }^{7}$ The results are reassuring. Compared across these four variables, subdistricts containing branches for which we have a petition do not significantly differ from subdistricts containing branches without a petition. In other words, our petitions seemingly do not come from areas with populations that were statistically different on key socioeconomic indicators from areas where we know the

\footnotetext{
${ }^{7}$ Note that points are jittered to reduce overplotting.
} 
Brotherhood had a presence, but for which we lack petitions.

Were those who signed the Muslim Brotherhood's petitions members of the movement? The answer is almost certainly yes. In 1941, putting one's name, occupation, and place of residence on a petition demanding that a wartime government release political prisoners surely constitutes high-risk activism (McAdam, 1986, 67). Indeed, the wording of these petitions was nakedly confrontational. Below is the text of the petition sent from the Brotherhood's Shubra branch in Cairo:

In the Name of Allah, the Merciful and Compassionate, His Excellency the Virtuous and Rightly Guided King, The signatories on this [petition], the people of Shubra Quarter, condemn the assault against the [peoples] Islamic feelings and the aggression against the carriers of the banner of Islamic preaching. [This aggression manifested itself] in the arrest of the honourable Mr. Hassan al-Banna, General Guide of the Muslim Brothers and Mr. Ahmed Sukkari, Deputy Director, and Mr. Abd al-Hakim Abdin, General Secretary of the [Muslim] Brothers. They [the people of Shubra] believe that such behaviour [taking place] in the specific conditions [we face] today are not in anyones interests, and may lead to the most sinister consequences (our emphasis).

It seems reasonable to assume that only committed movement supporters would put their name to such a provocation. ${ }^{8}$

Additional triangulation with Muslim Brotherhood branch surveys confirms that petitions came from subdistricts that also hosted formal Brotherhood branches. The language at the head of the petitions is almost identical, suggestive of the fact that these petitions were coordinated by the movement's central organization. Finally, there is direct evidence that the signatories included Muslim Brotherhood members. While detailed membership lists for this period do not survive, branch surveys published in ${ }^{8}$ Discussing the late 1800 s, Cole $(1999,159)$ notes that signatories to petitions, particularly those addressed to political authorities, assumed "extreme risk" and only tended to sign their name — as opposed to submitting anonymously — as a sign of political commitment. 
Figure 4: Muslim Brotherhood branch

Figure 5: Shubra petition survey, 1940

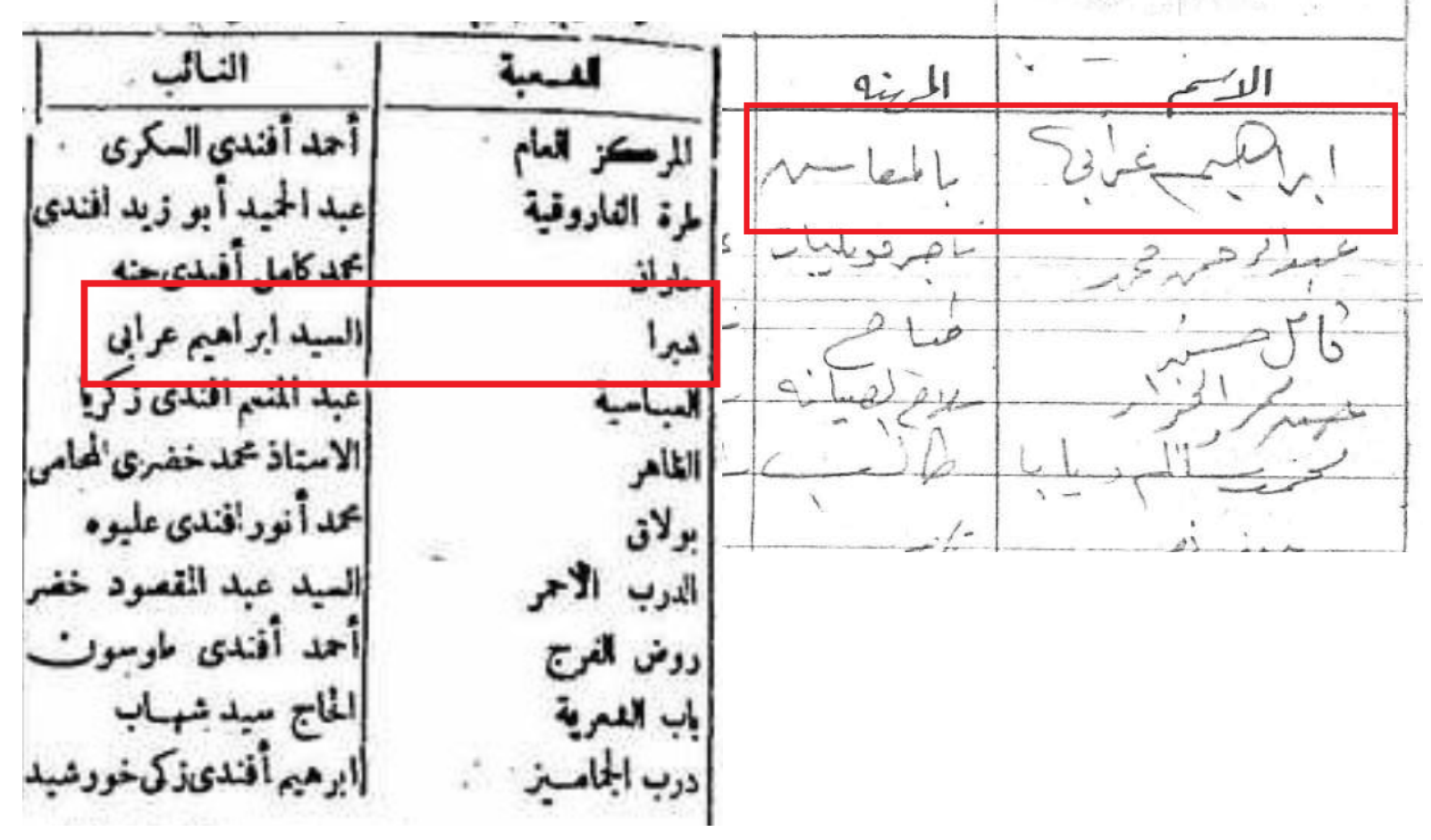

the Muslim Brotherhood's newspaper in 1937 and 1940 did record the names of branch leaders. To give an example: Figure 4 is the branch survey for Cairo. Note that the branch leader for the Shubra subdistrict is recorded as "Ibrahim Urabi." Figure 5 shows a fragment of the petition sent by the Shubra branch, showing what is assumedly the signature of the same person. As we set out in Section 7 in our analysis of Brotherhood branch formation in Gamgara al-Gadida, triangulation with additional evidence from contemporary Brotherhood sources identifies dozens of signatories as Muslim Brotherhood members.

To compare Muslim Brotherhood supporters against the underlying population, we draw on appendices to the 1937 Egyptian census (the most recent census for our analysis period). These appendices record district-level literacy rates and disaggregated employment data by occupational sector and are held in paper format in the library of the American University in Cairo and the Egyptian National Library. To deepen our understanding of the statistical findings, we also consulted the branch surveys and articles published in Muslim Brotherhood newspapers held at the libraries of Columbia 
University and Harvard University. We also draw on British intelligence reports on the Muslim Brotherhood stored at the British National Archives. Finally, to identify the land holdings of Muslim Brotherhood members we digitized a contemporaneous 1:25,000 scale maps series of Egypt published by the Survey of Egypt (1945) and held at the Library of Congress.

\section{Descriptive analysis}

Figure 6 assigns signatories to their occupational sector using the categories recorded in the 1937 census. Several trends are noteworthy. The modal signatory (34 percent) was employed in commerce. This would seem to align with qualitative accounts of the early Muslim Brotherhood that stress the role of "petty bourgeois" merchants and traders. Other prominent sectors are agriculture (32 percent) and public administration (9 percent). The prominence of signatories employed in the agrarian economy is striking and would seem to contradict the case literature, which emphasizes the relative absence of agricultural workers in the Brotherhood's ranks. Figure 7, which reports the proportion of adults employed in Egypt by occupational sector as recorded in the 1937 census, helps us to make sense of this apparent discrepancy. In the period prior to the petitions being compiled, nearly 60 percent of the adult population worked in this sector. Viewed against this backdrop, Muslim Brotherhood supporters employed in the agrarian economy were, in fact, underrepresented given the prevalence of agricultural workers in the overall workforce. While the raw numbers suggest that the Brotherhood was able to command more support from agrarian workers than is typically accounted for in the case literature (a point we return to in Section 7), this underlines the importance of comparing samples of Islamists to the underlying population from which they are drawn (see Ketchley and Biggs 2017).

Figure 8 provides a more sophisticated analysis, plotting the average number of Muslim Brotherhood supporters by occupational sector in a district against the district average of adults employed in those sectors. To account for uncertainty, district averages 
Figure 6: Muslim Brotherhood supporters by occupation, 1941

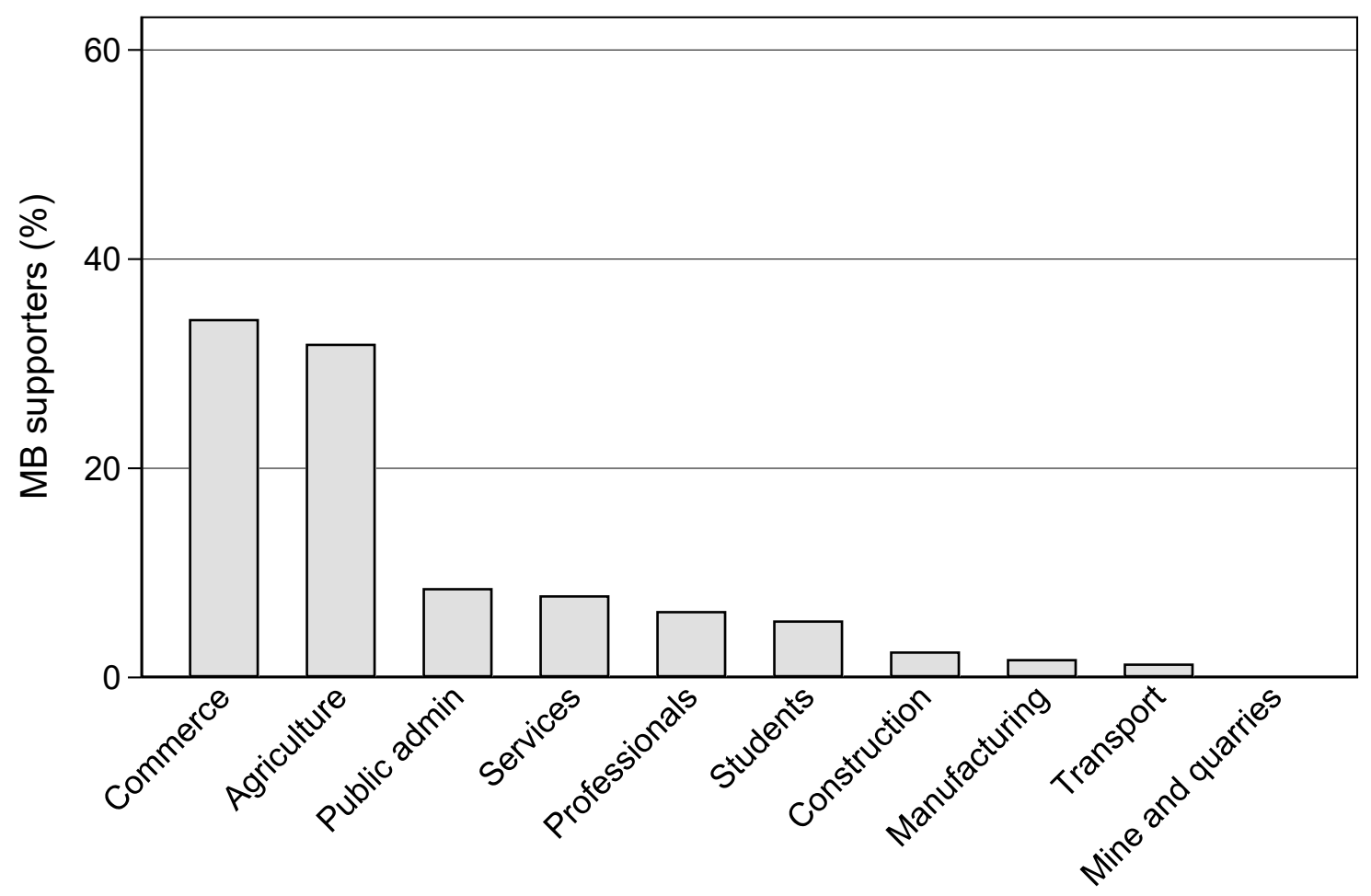

Figure 7: Egyptian occupations, 1937

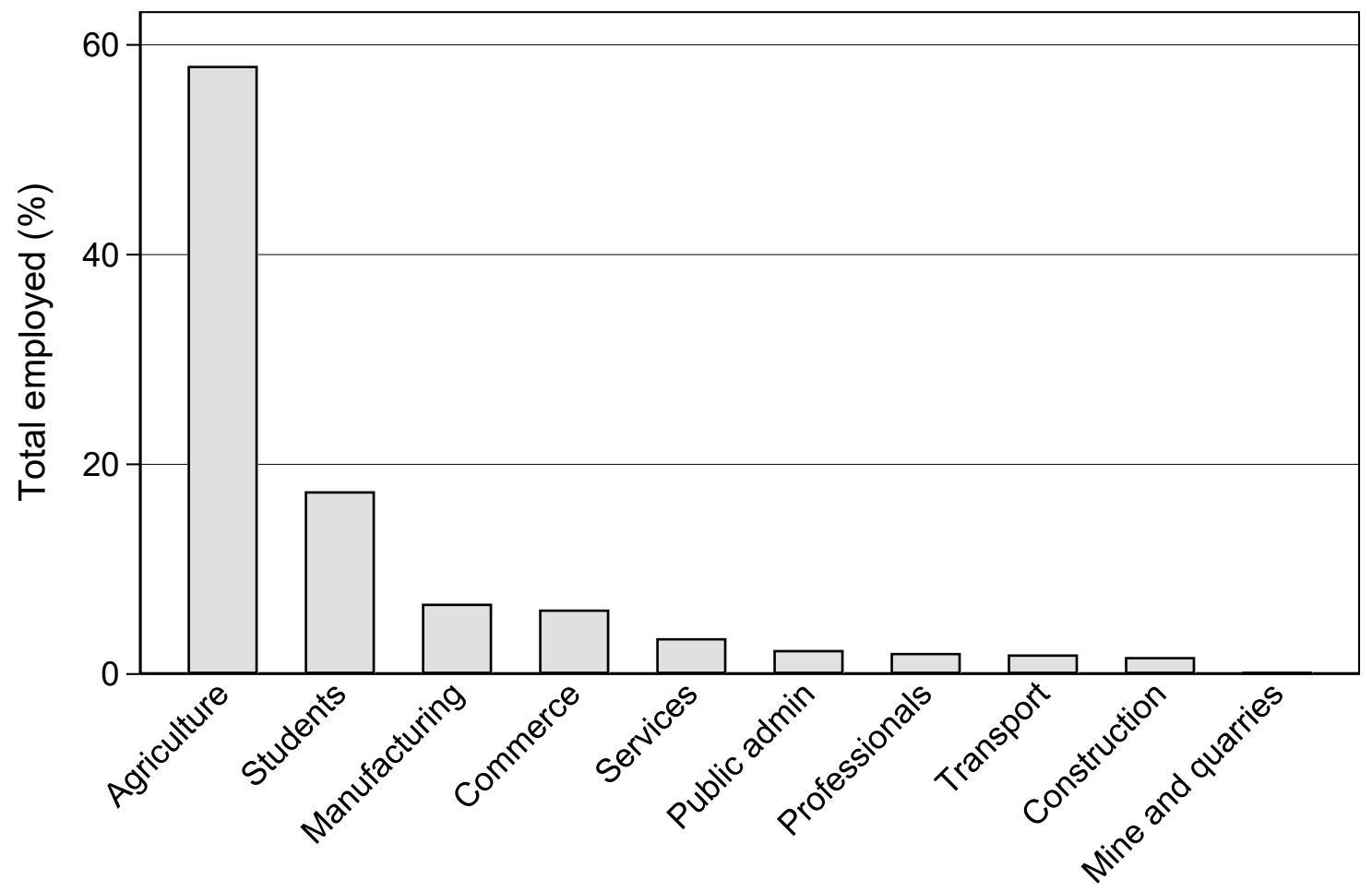



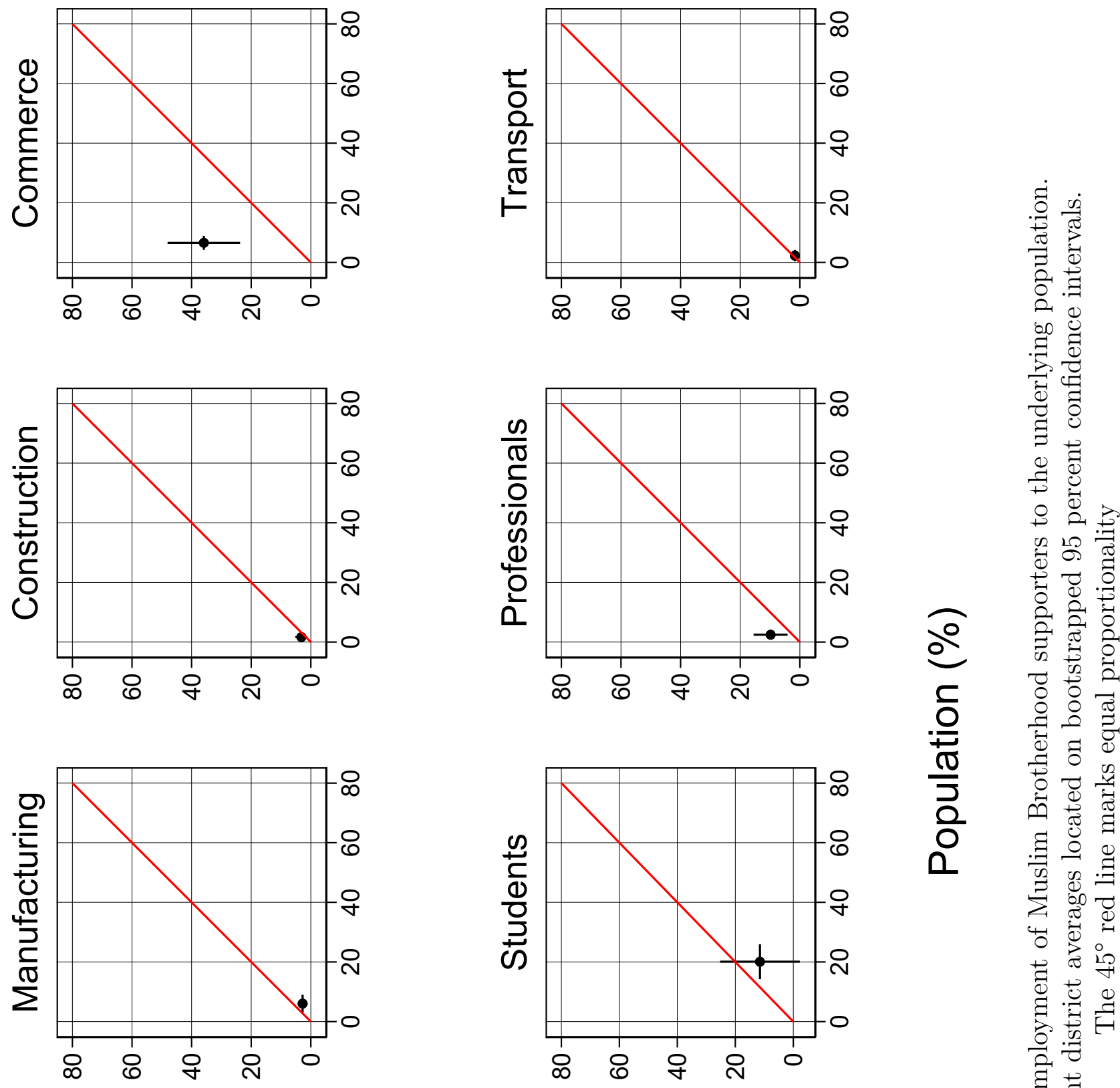

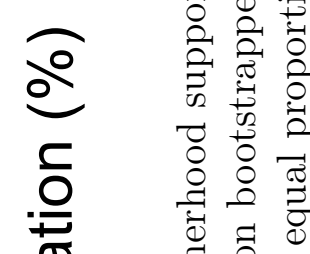

흥 苋焉

$\therefore$
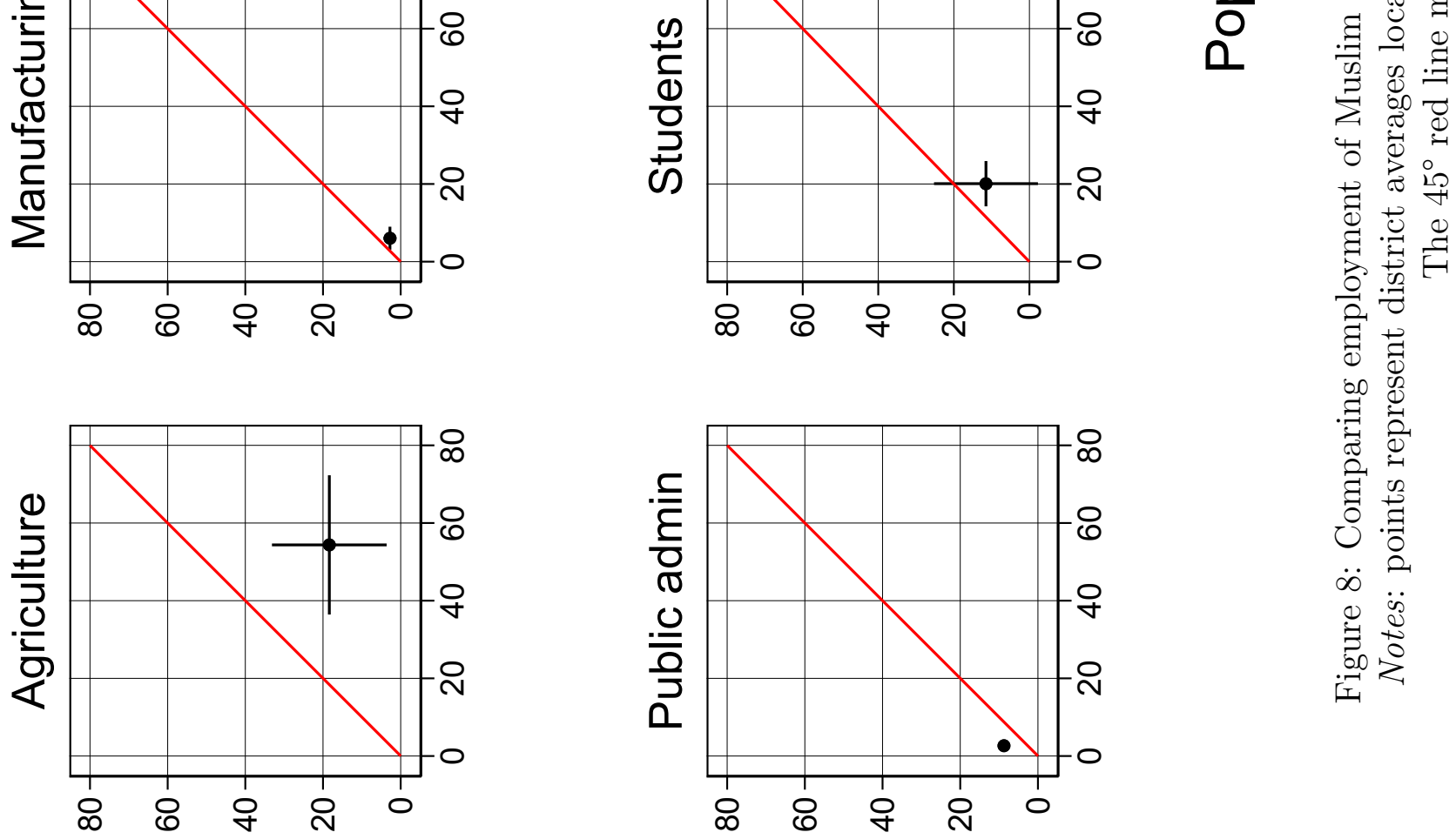

(\%) sıəjoddns gW 


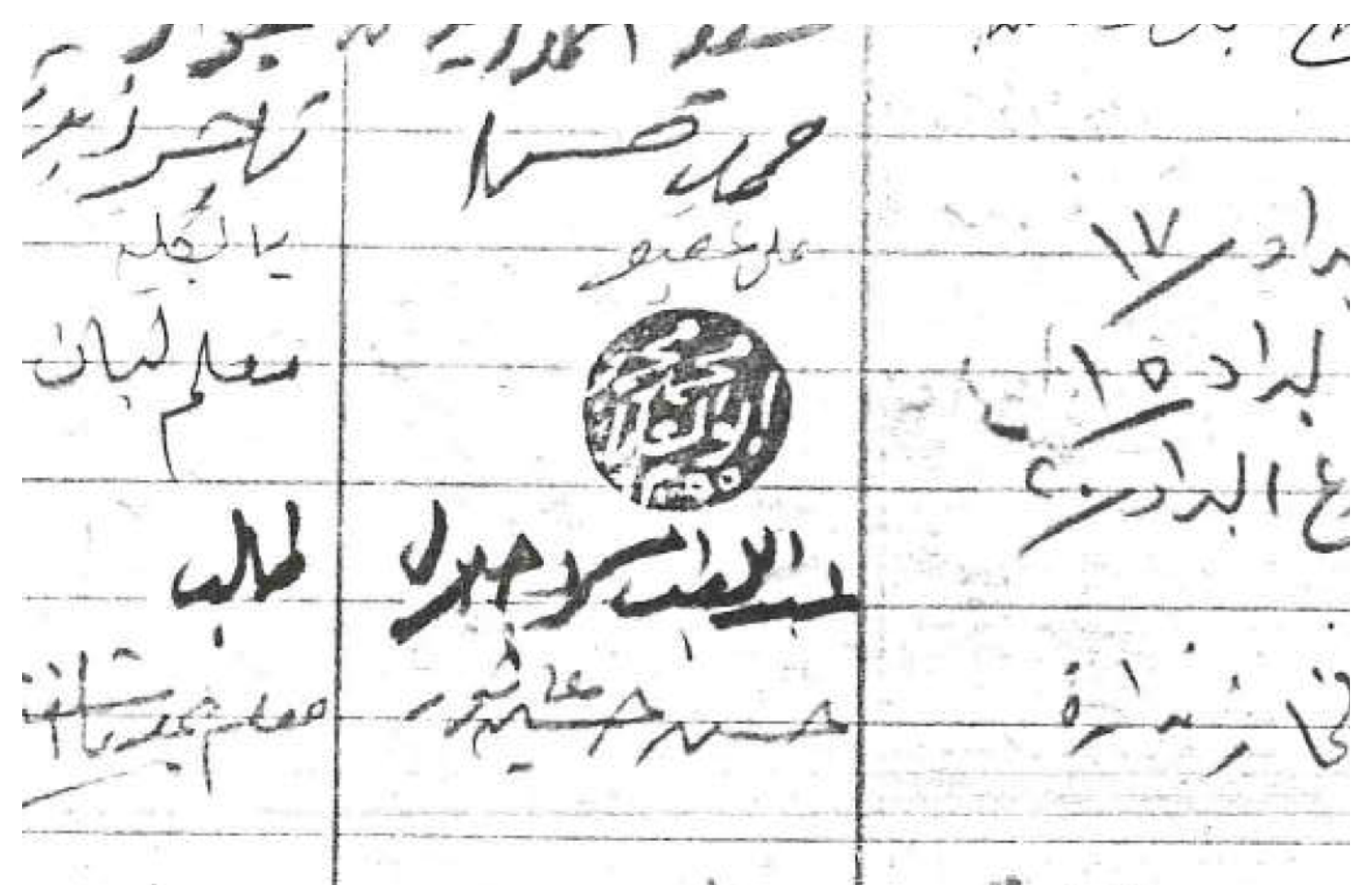

Figure 9: Stamp of Muhammad Muhammad Abu al-'Alaa, Shubra petition.

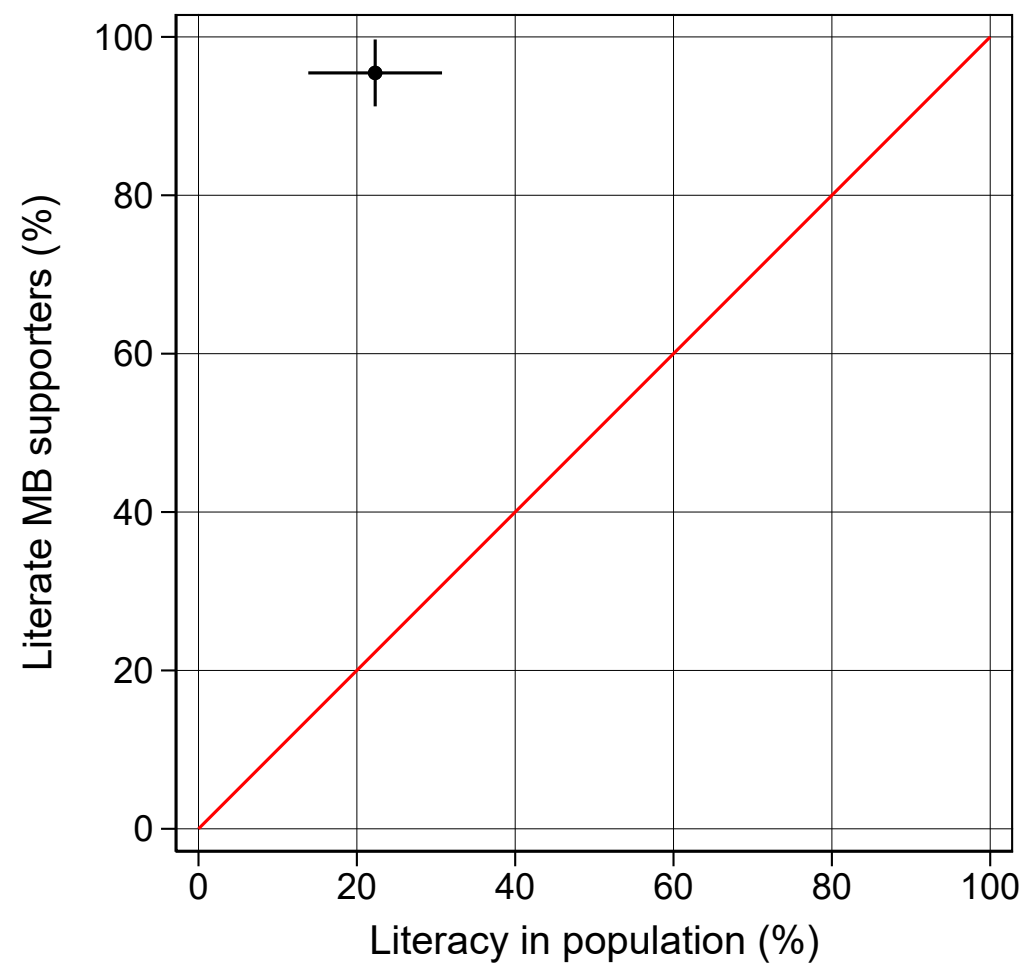

Figure 10: Comparing literacy of Muslim Brotherhood supporters to the population. Notes: the point represents the district average located on bootstrapped 95 percent confidence intervals. The $45^{\circ}$ red line marks equal proportionality 
are located on 95 percent confidence intervals calculated using the bootstrap. The $45^{\circ}$ red diagonal line marks equal representation. Points above the line indicate sectors that are over-represented amongst Muslim Brotherhood supporters compared to the population, while points below the line indicate underrepresentation. Where the confidence intervals cross the red line, we cannot reject the null hypothesis of equal proportionality. The findings are suggestive. Across the eight districts for which we have Muslim Brotherhood petitions, the mean proportion of adults employed in agriculture was 54 percent (95\% CI $[36,72])$. This contrasts with an average of 18 percent $(95 \%$ CI $[3,33])$ of Muslim Brotherhood signatories being employed in agriculture. We cannot reject the null hypothesis of equal proportionality for students and those employed in construction and transport. Interestingly, the percentage of Muslim Brotherhood supporters employed in manufacturing was 2.7 percent $(95 \%$ CI $[1,4])$, compared to six percent $(95 \%$ CI $[3,9])$ of adults in the districts for which we have petitions. Most importantly, the proportion of Muslim Brotherhood signatories employed in commerce, public administration, and professional occupations is much greater than we would expect, given the number of adults employed in those sectors. ${ }^{9}$

We can also use the petitions to arbitrate the other key claim raised in the literature: that early Islamist movements attracted the support of literate Muslims. In interwar Egypt, illiterate adults used stamps to certify documents and sign petitions in lieu of a hand-written signature. ${ }^{10}$ Figure 9 is an example stamp recorded in the aforementioned Muslim Brotherhood petition sent from Shubra in Cairo. The stamp bears the name Muhammad Muhammad Abu al-Alaa, whose stated profession roughly translates to "milk seller." Visual inspection of the petitions points to a multitude of different hand writing

\footnotetext{
${ }^{9}$ Note that among Muslim Brotherhood supporters assigned to the "professionals" census category, 26 self-identified as a lawyer (17 percent). Teachers were the most frequently recurring type of professional employment (50 percent).

${ }^{10}$ As Chalcraft (2004; 2005) chronicles, illiterate Egyptians frequently participated in petition campaigns. Such was the demand for petitions from illiterates that there was a guild of petition writers who would compose the text of the petition, and then the petitioners would either sign or stamp the petition depending on their literacy status.
} 
styles, suggesting that petitioners likely signed the petitions themselves, as opposed to an enumerator or scribe filling in the petition for them. As above, Figure 10 plots the mean percentage of Muslim Brotherhood supporters in a district who signed the petition using a hand-written signature against the average literacy rate in the districts that they came from. Across the 8 districts that produced petitions, the mean literacy rate was 22 percent $(95 \%$ CI $[14,30])$. It is striking then that, when comparing across those same districts, the average literacy rate amongst Muslim Brotherhood supporters was fully 94 percent $(95 \%$ CI $[91,99]) .{ }^{11}$ This provides empirical confirmation that the rank-and-file supporters of the early Muslim Brotherhood were more likely to be drawn from literate Egyptians in the areas where the movement was active.

\section{Multivariate analysis}

To have confidence that certain occupations were under- or over-represented, multivariate methods are required. In particular, unobserved contextual factors may have shaped the rate at which different occupations signed the Brotherhood's petitions. The intraclass correlation from an empty model suggests that around 16 percent of the variation in the signing rate across occupations comes from differences between signatories' districts. ${ }^{12}$ To model these contextual factors, the unit of analysis is an occupational sector in a district. For each district, the census has records for 11 different occupational sectors. Sectors with no employment in a district are naturally excluded from the analysis. Petitions exist for 15 Muslim Brotherhood branches located in eight districts. Signatories are assigned to the relevant occupational category in their home district. The dependent variable is thus a count of signatories. This has a variance that is considerably greater than its mean, and so is modeled using negative binomial regression. Let the outcome be $\mu_{i d}$, indexed

\footnotetext{
${ }^{11}$ Logistic regression suggests that petition signatories employed in the agrarian economy were 9.2 times more likely to use a stamp, as compared to individuals employed in other sectors $(\mathrm{p}<.001)$.

${ }^{12}$ To estimate the intraclass correlation for a hierarchical negative binomial model, we use the Stata code provided by Leckie et al (2019).
} 
by occupation $(i)$ in district $(d)$. We estimate this as:

$$
\widetilde{\mu}_{i d}=\exp \left(\sum \beta_{k} X_{k i}+\zeta_{d}\right) E_{i d} \delta_{i d}
$$

where the number of adults employed in an occupation in a given district, $E$, is the exposure term. With twice as many individuals employed in a given occupation in a district, we expect twice as many signatories. Following the literature and the descriptive analysis above, the number of signatories in an occupation relative to the economically active population in a district is explained by a vector of dummy variables, $X_{k}$, capturing sectors related to agriculture, manufacturing, commerce, public administration, and professional employment. To ensure that the rate of signing is not driven by omitted factors stemming from differences between signatories' districts, we include a fixed intercept for each district, $\zeta_{d}$, which absorbs the unique characteristics of each one and confines attention to variation across occupational sectors within the same district. The disturbance term, $\delta$, is drawn from the Gamma distribution with a mean of 1 . Standard errors are adjusted for clustering by district.

\subsection{Results}

Table 1 are the results with coefficients expressed as incidence-rate ratios (the exponent of the $\beta$ coefficient). Comparing across occupational sectors within a given district, the signing rate was 4.14 times greater amongst those employed in commerce. Similarly, the signing rate was 2.85 times greater for professionals and 2.66 times higher among those employed in public administration assuming equal proportionality. In line with the descriptive analysis, the agrarian economy produced on average 77 percent fewer signatures than we would expect given the number of adults employed in that sector, while manufacturing saw 72 percent fewer signatories. All of these associations are statistically significant at $\mathrm{p}<.05$.

Table 2 tests several alternative specifications, including a mixed effects negative binomial model with random intercepts at the district level, a fixed effects OLS model, 
Table 1: Predicting the number of signatories by occupational sector

\begin{tabular}{lccl}
\hline & irr & z-score & p-value \\
\hline Commerce & 4.14 & 4.12 & $.00^{* * *}$ \\
Professionals & 2.85 & 2.09 & $.04^{*}$ \\
Public administration & 2.66 & 3.93 & $.00^{* * *}$ \\
Agriculture & 0.23 & -3.68 & $.00^{* * *}$ \\
Manufacturing & 0.28 & -3.39 & $.00^{* * *}$ \\
Intercept for each district & & $\checkmark$ & \\
Alpha coefficient & 0.75 & 6.66 & $.00^{* * *}$ \\
\hline Districts & & 8 & \\
Occupational sectors & & 85 & \\
\hline
\end{tabular}

\footnotetext{
Negative binomial regression with $\ln ($ employed in sector) exposure P-values (two-tailed); ${ }^{* * *} \mathrm{p}<.001 ;{ }^{* *} \mathrm{p}<.01 ;{ }^{*} \mathrm{p}<.05$
}

and a fixed effects Poisson model. To ensure comparability across models, we leave the beta coefficients of the negative binomial and Poisson models unexponentiated. Some sectors in some districts produced zero signatories. For the OLS model, the dependent variable is thus transformed to the inverse hyperbolic sine as log zero is undefined. ${ }^{13}$ Across all models, the commerce, professional and public administration sectors produced more signatories - and these associations are again statistically significant. The findings for agriculture and manufacturing are more ambiguous; while the coefficients are always negatively signed, they drop in and out of statistical significance depending on how we model the signing rate.

\footnotetext{
${ }^{13}$ Given the small number of clusters, we also re-ran the OLS model using the wild cluster bootstrap-t procedure. Again, the results are unchanged.
} 


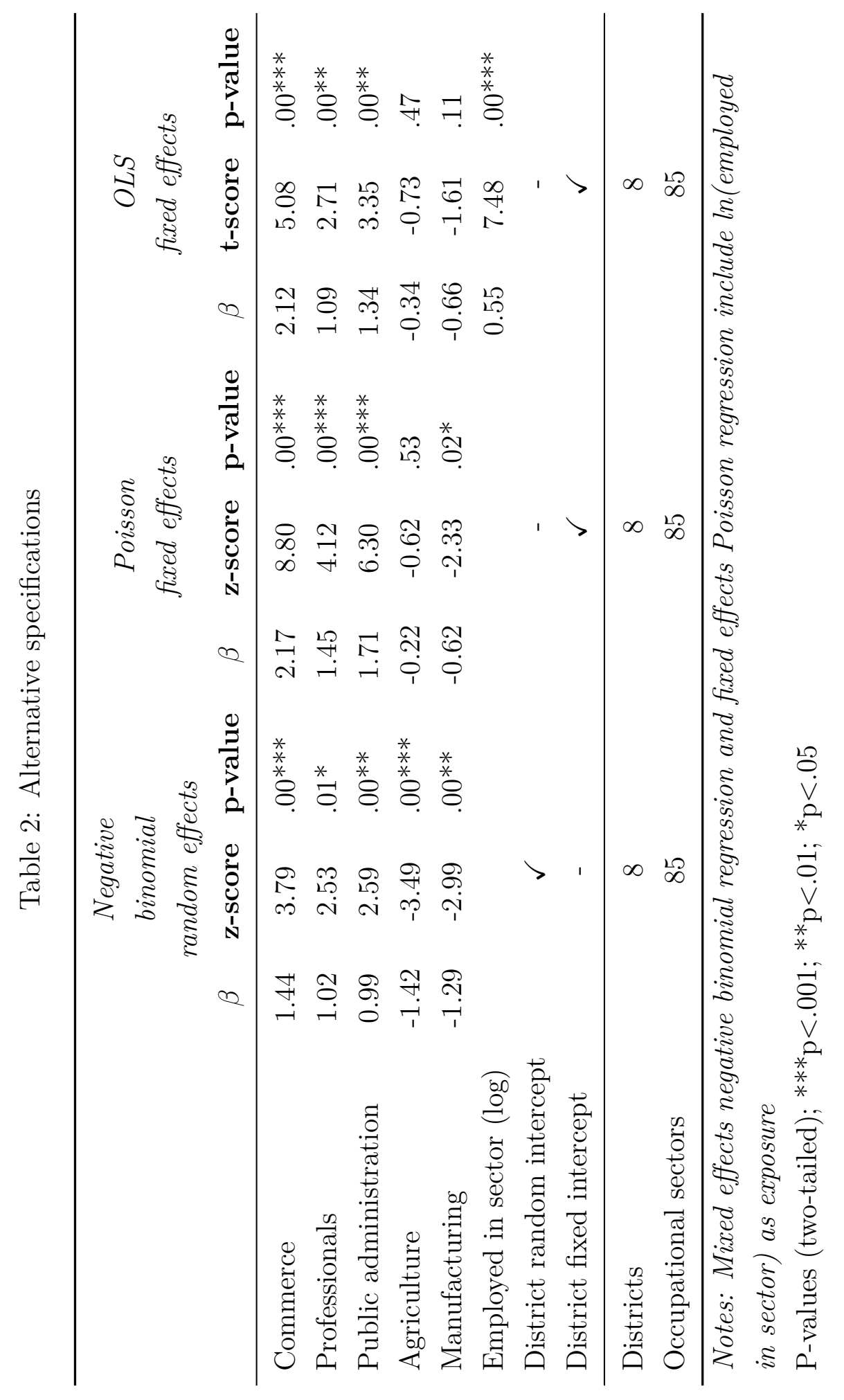




\section{Two Families of Gamgara al-Gadida}

In this section, we process trace the involvement of two families from the Nile Delta village of Gamgara al-Gadida in the Muslim Brotherhood, from the local chapter's formation there in 1936 to the issuance of the petition in 1941 (George and Bennett, 2005). This more "intensive study of a single unit" (Gerring, 2004, 342) helps provide broader insights into how, in more rural areas, the Brotherhood managed to appeal to literate, socially mobile populations that were on the periphery of traditional political networks. Relatedly, by selecting into a rural area, this case study also provides confidence that assigning petitioners into the coarse employment category of "agriculture" given in the census is likely not mis-categorizing large landowning Muslim Brotherhood supporters as agrarian workers.

Figure 11 shows the location of Gamgara al-Gadida relative to Cairo and the Nile Delta. Figure 12 plots the percentage of the population employed in agriculture against the literacy rate using subdistrict-level data recorded in the 1937 census. During this period, in the median subdistrict around 33 percent of the population were employed in the agrarian economy, with 12 percent literacy. Against this backdrop, the social composition of Gamgara al-Gadida is striking, being both more agrarian and more literate than the typical subdistrict.

According to a report published in their newspaper al-Nadhir, the Muslim Brotherhood established a branch in Gamgara al-Gadida on July 27, 1936, approximately five years before the petitions were sent. In addition to listing the founding officers, that 1936 dispatch also noted the participation of two local notables. The umda, Ahmed Bey Abdel Rahman Nuseir, was made an "honorary president" (ra'isan sharifan) of the new branch (a local shaykh was pronounced the actual branch president), while the village shaykh al-balad, Ali Hasan El-Guindi, was made an "honorary member." These village positions, often roughly analogized to mayor and deputy sheriff, sat at the intersection of family status and political power in rural Egypt (Baer, 1969). The Brotherhood's engagement of these two individuals was deft politics: as Lia (1998, 186-190) notes, during their early years the Brotherhood used honorary titles like these to co-opt local elites, 


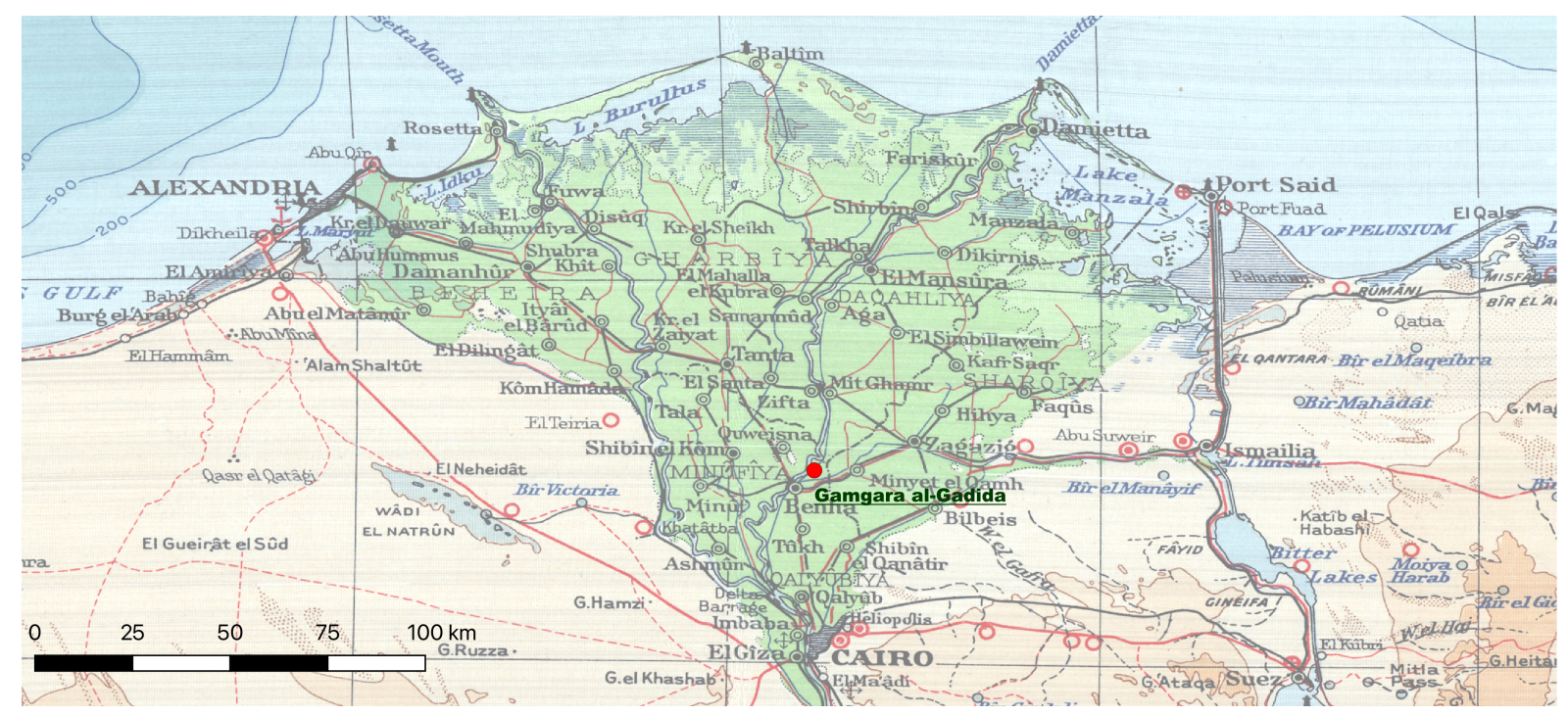

Figure 11: Inset showing Gamgara al-Gadida from "Egypt, geological: Compiled, drawn and printed by the Department of Survey and Mines, Giza, Egypt, November 1937"

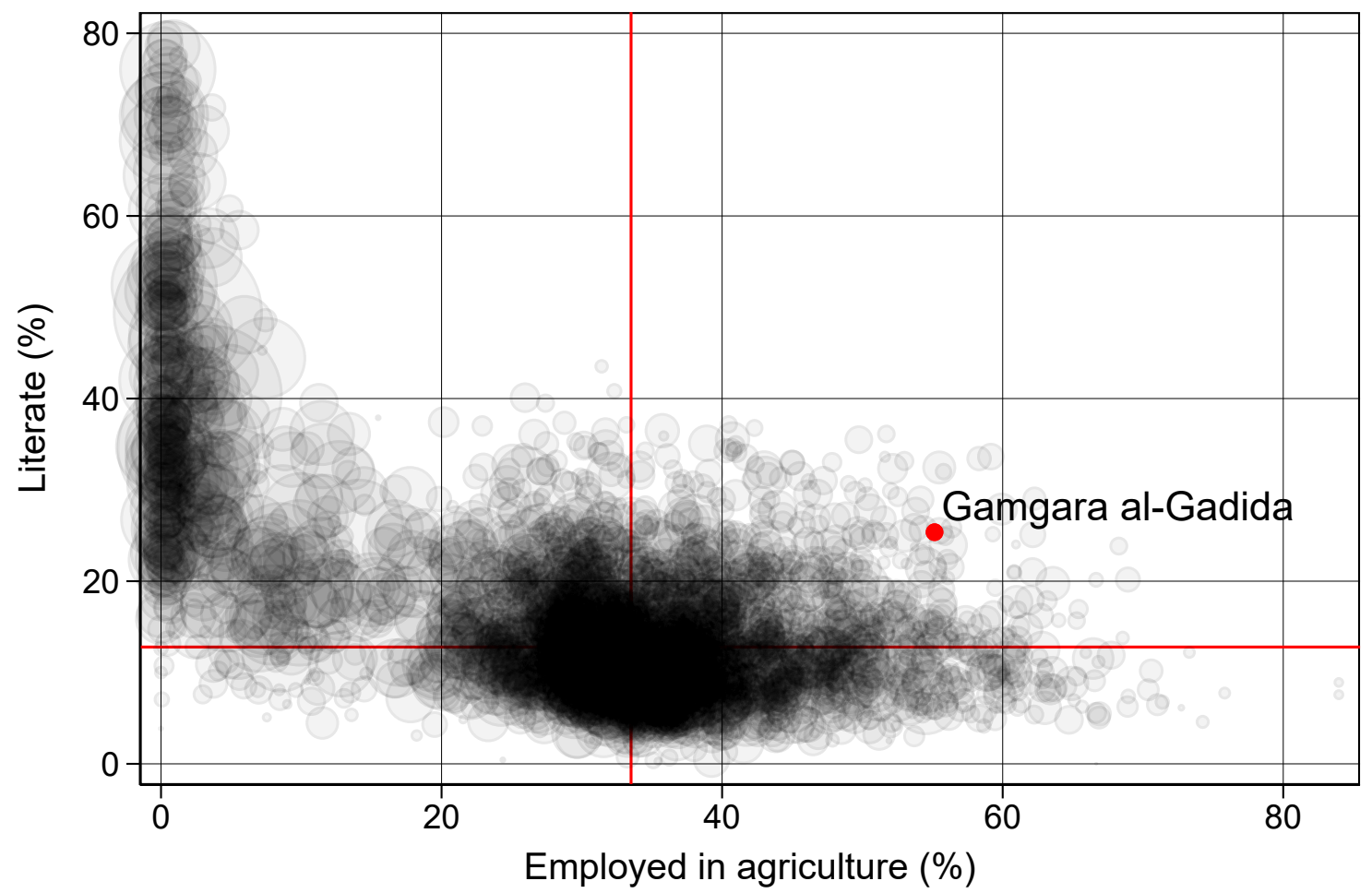

Figure 12: Employment in agriculture and literacy rate by subdistrict, 1937. Notes: red lines mark the median subdistrict. Points are weighted by total population 

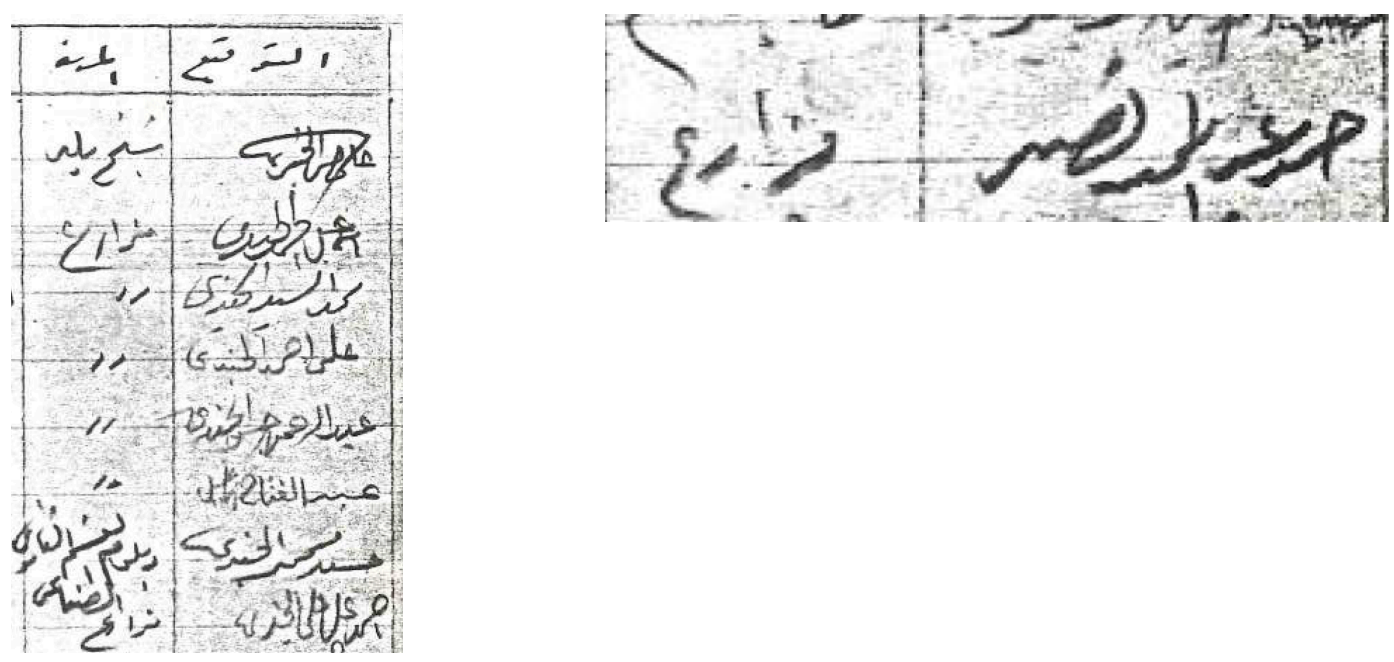

thus gaining legitimacy, social acceptance, and access to local networks and associational spaces. ${ }^{14}$

If these two families' positions, as umda and shaykh al-balad, underlines their importance in the social structure of Gamgara al-Gadida when the Muslim Brotherhood arrived in 1936, their participation in the Brotherhood's petition drive five years later was quite different. Figures 13 and 14 show the participation of members of these two families in the petition sent by the Muslim Brotherhood branch in Gamgara al-Gadida (these are insets of Figure 2). Figure 13 shows that seven of the first eight signers of the petition hailed from the El-Guindi family. They are led by the assumed patriarch, Shaykh Ali Hassan El-Guindi, the aforementioned shaykh al-balad, who signed the petition first. The fifth signatory of the petition in Figure 13, Abdel Rahman El-Guindi, was listed in the

\footnotetext{
${ }^{14}$ Why did local elites accept these honorary roles? It bears remembering that in the mid-1930s, the Brotherhood was still a relatively unknown entity at a time when religious societies and associations were increasingly common. Against this backdrop, an affiliation with the movement may have appeared as a benign, even routine, way for notables to reaffirm their societal and political dominance. The Young Men's Muslim Association, for example, of which al-Banna was a member, had made great use of such affiliations to build their movement. Importantly, this practice of granting honorary positions to notables declined in later periods, either because the Brotherhood was sufficiently well established so as to not require their patronage, or else because notables became wary of any association with alBanna's agenda. What is also evident is that these notables rarely, if ever, assumed leadership positions in the movement, suggesting that these relationships were largely transactional and short-lived.
} 
al-Nadhir dispatch as the branch's founding treasurer. ${ }^{15}$ And throughout the remainder of the petition, the El-Guindi family is by far the most prevalent: of the 145 signatories (96 of whom were employed in agriculture, 64 of whom were literate), at least 18 members of the El-Guindi family signed demanding the release of the Brotherhood's leaders. In contrast, Figure 14 shows the only signatory from the Nuseir family, even though that family had been notable enough to furnish the branch's honorary president when it was founded in 1936. The divergent participation of these two families provides important insights into the Muslim Brotherhood's ability to mobilize outside of Egypt's cities, as well as their tendency to attract support from certain social formations.

Uniquely, we are able to reconstruct these families' roles in the local ecology of Gamgara al-Gadida. Figure 15 shows a close up of Gamgara al-Gadida taken from a contemporaneous, 1:25,000-scale map series of Egypt. This particular map series is instructive for how it precisely charts the extent of local landholdings, in particular the 'izba (pl. 'izab), an institution of coercive agriculture roughly equivalent to a plantation that was central to cotton production (Mitchell, 2002; Abaza, 2013). Thousands of these 'izab dotted the Egyptian countryside during the early 20th century, and the family names attached to each, along with their locations, shed light on the village's local landowning class (Survey of Egypt, 1932). 'Izba are identified on the map in Figure 15 by a dotted polygon and denoted by the prefix "Ez." followed by the name of the owner, which allows us to cross-check local landholdings with the prominent families listed above.

As Figure 15 illustrates, Gamgara al-Gadida was surrounded by seven 'izab operated by members of the Nuseir family. Note that the aforementioned umda and honorary branch president in the 1936 report of the branch founding is almost assuredly the same

\footnotetext{
${ }^{15}$ Indeed, the El-Guindi family was also overrepresented in the actual, as opposed to honorary, leadership of the branch. Of the six founding officers, three were members of the El-Guindi family: Hag Abdel Rahman Hasan El-Guindi was the branch's treasurer (amin al-sunduq), Mohammed Effendi Ahmed El-Guindi was was the Assistant Secretary (sekretar musa'id), and Shaykh Ahmed Mohammed ElGuindi was the Observer (muraqib). Though not from these two families, other founding Muslim Brotherhood branch members were also among the signatories, including Shaykh Mohammed 'Afifi Saleh, the founding deputy leader, and the founding secretary, Mohammed Metwali Mansour.
} 
Figure 15: Map sheet showing Gamgara al-Gadida in Banha, Qalyubiyya

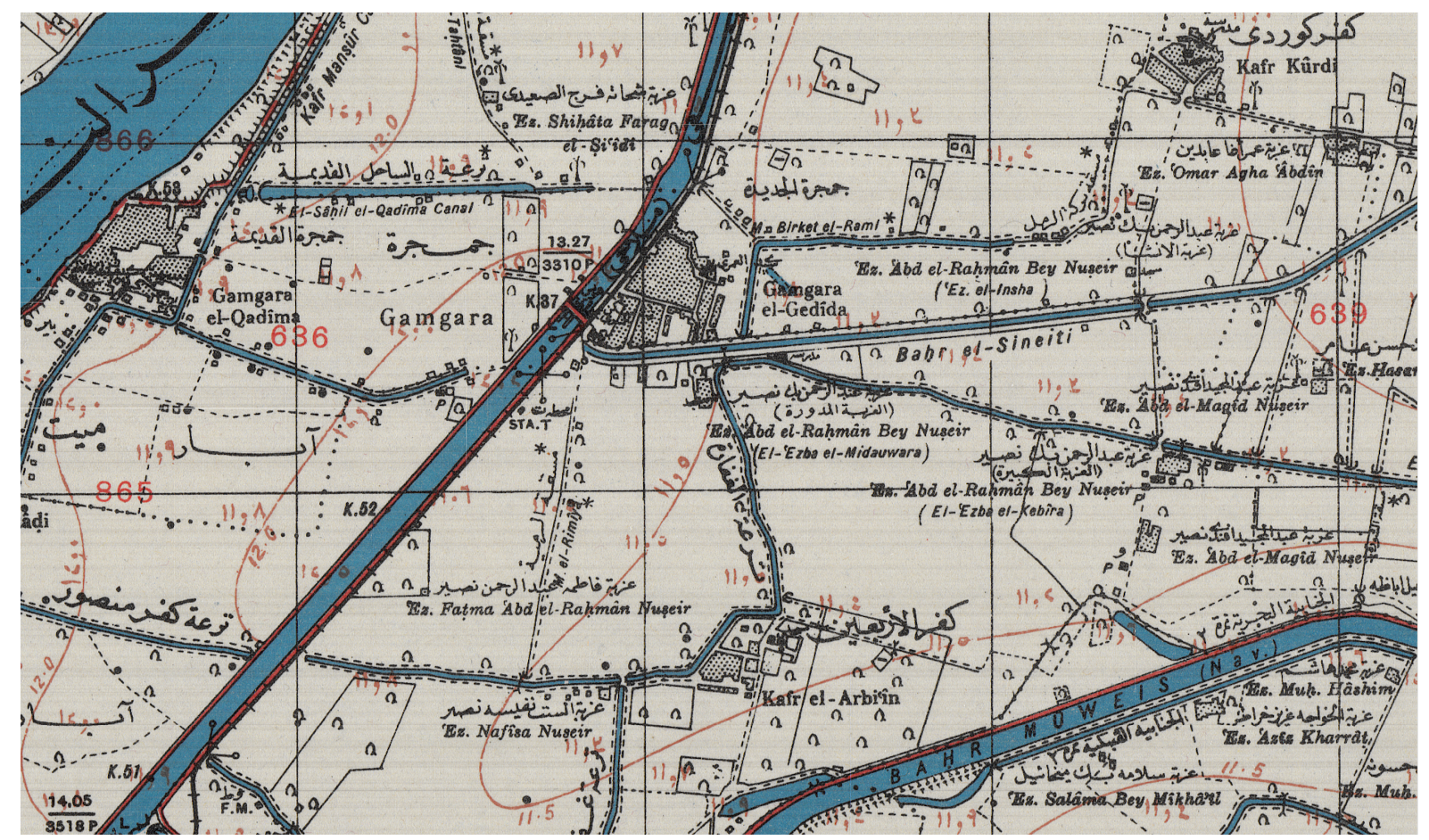

"Abd el-Rahman Bey Nuseir" who owns the three prominent 'izab proximate to the village in Figure 15. ${ }^{16}$ Assumedly, the literate farmer "Abd el-Meguid Nuseir" who signed the 1941 petition (Figure 14) is also the same "Abd el-Magid Nuseir" of the two eponymous ' $i z a b$ further west of Gamgara al-Gadida in Figure 15. These maps support the implication of the Brotherhood's own report of the branch's founding, in that this particular family possessed considerable economic influence in the area, evidenced by their extensive landholdings.

Additional documentation helps us to uncover the Nuseir family's national political power and further clarifies their relationship to the Brotherhood. A June 1932 British Foreign Office document listing the names and dispositions of hundreds of local families towards the government identifies a "Nosseir" family from the same district as Gamgara al-Gadida as being broadly supportive of the government (Foreign Office, 1932, 11). More directly, two months before the founding of the Muslim Brotherhood's branch in Gamgara al-Gadida, the Egyptian national daily newspaper al-Ahram (May 4 1936) records that

\footnotetext{
${ }^{16}$ In other sources, Nuseir is also recorded as being a "notable," indicating that he was also a significant landowner (see Subhi, 1939, 177).
} 
the aforementioned Ahmed Abdel Rahman Nuseir — the umda and honorary Muslim Brotherhood branch president — was elected to the Egyptian Parliament as a member of the Wafd. Of course, Nuseir could have been supportive of the Brotherhood even as he remained within the fold of the Wafd, although the fact that he did not personally sign the petition calling for the release of the movement's leadership suggests that his commitment to the Brotherhood was not particularly strong. This is further evidenced by the fact that Nuseir was later re-elected as a Wafdist MP in the parliamentary elections of 1942 (al-Ahram, March 25, 1942) despite senior Wafdist politicians conspiring with the British to bar Muslim Brotherhood members from contesting that election (Heyworth-Dunne, 1950, 40). These details bring the social standing of the Nuseir family into somewhat sharper relief: as members of the economic and political elite, not just in the vicinity of Gamgara al-Gadida, but also stretching into national political circles. ${ }^{17}$

Despite its significant presence on the petition, the El-Guindi family, in contrast, is conspicuous in its absence from other sources. We cannot find any trace of landholdings in the vicinity linked to this family, implying that the El-Guindi's were smallholders; a 1913 law stipulated that new ' $i z a b$ could not be smaller than 50 feddans, a considerable amount of land. ${ }^{18}$ Nor are they detectable in any contemporaneous Foreign Office reports or election results. The El-Guindi family likely represents what Nathan Brown (1990a) has called the "agricultural middle class." Families in this class would not have been without means; their economic position would have been sufficient to access some of the fruits of modernization, namely education. As Binder explains "such families are usually able to afford educating at least some of their sons, and thus able to help them attain urban, educated middle class status" $(1978,29)$. The breakdown of the eighteen ElGuindi family signatories on the petition is suggestive of this trajectory: two members

\footnotetext{
${ }^{17}$ In the Egyptian version of Who's Who (1937, 69), Nuseir gives his residential address as Heliopolis, an exclusive neighborhood in Cairo out of reach for all but the wealthiest Egyptians. Tellingly, the Muslim Brotherhood did not establish a branch in Heliopolis during this period, suggesting that Nuseir was not active in propagating the movement.

${ }^{18}$ Brown $(1990 a, 149-150)$ and Binder $(1978,29)$ both categorize this new middle class as landowners of around 5-10 or, at most, 50 feddans.
} 
worked in commerce, two in local public administration, three were students, and one worked in the service sector. The ten remaining members listed their occupation as farmers. Going by their ability to sign their own names, rather than using stamps, all were literate. This locally important but relatively unknown family seems more typical of Muslim Brotherhood supporters in our petitions data; similar attempts to match petition signers from other villages to owners of nearby ' $i z a b$, election, and archival data yielded very few obvious matches.

These families' respective histories suggest one reason for the Muslim Brotherhood's success across Egypt's villages and hamlets. It is consistent with the evidence that the Nuseir family's considerable status — both in Gamgara al-Gadida and beyond — required the Muslim Brotherhood to grant a sinecure to its patriarch as a condition of establishing a presence in the village. But the Nuseir family's commitment to the Brotherhood seems to never have been more than titular; their extensive landholdings and political loyalty to the Wafd — the political home of Egypt's landowning class - likely imposed a natural brake on members of this elite family's willingness to rally behind a movement like the Muslim Brotherhood. Indeed, by the late 1930s, the Brotherhood was in open conflict with the Wafd, in part due to al-Bannas increasingly public criticisms of the 1937 AngloEgyptian Treaty, and in part due to the patronage that the Brothers received from the Egyptian Palace, which saw religious movements as a popular counterweight to the Wafds parliamentary authority (see especially Tripp 1984). The El-Guindi family, in contrast, represented a new rural stratum in an increasingly literate society that had been hitherto overlooked by Egypt's political elite. Members of this inchoate class were still tied to the agrarian economy, yet they had also begun to benefit from expanding opportunities for schooling that brought along with it literacy, participation in modern sectors of the economy, and political aspirations. Yet despite their improving social and economic position, their ability to engage in politics remained constrained by the patron-client networks that structured Egyptian political life. Against this backdrop, the Muslim Brotherhood's expansion into rural areas in the 1930s was well timed to integrate this new constituency into novel forms of political activism. 


\section{Conclusions and discussion}

A unique set of petitions from interwar Egypt allows us to systematically assess the social sources of support for early political Islam. As we have shown, individuals employed in commerce, government bureaucracy and the professions were much more likely to support the Muslim Brotherhood. Individuals belonging to these occupations were socially mobile, but otherwise overlooked by the country's political elite. Although underrepresented given their prevalence in the workforce, Egyptians employed in the agrarian economy were not completely absent from the Brotherhood's supporters. This represents a more nuanced picture than we get from the case literature. ${ }^{19}$ This point aside, our petition data on rank-and-file supporters otherwise aligns with earlier samples of the Brotherhood's more prominent members, suggesting that there was no real sociological distance between the leadership and the base of the movement. Our follow-on analysis of the rural town of Gamgara al-Gadida provides further detail on who these signatories were, in the process bringing into sharp relief those individuals who formed the core of the Brotherhood's support base in more rural areas. By comparing the rate at which individuals signed petitions to the underlying literacy rate in signatories' districts, we also provide the first systematic evidence that literate Muslims were, in fact, over-represented amongst the Brotherhood's ranks. Taken together, these results mark the first systematic attempt to use individual-level information to identify the social backgrounds of ordinary people who were motivated to support the first Islamist movements.

Our analysis suggests at least two directions for additional research. As noted, all the signatures on these petitions were male, although Egyptian women in this period did petition the the authorities to redress political grievances (Baron, 2005, 111-112, 167). This lack of overt female participation on the petitions should not be taken as evidence there was no female participation in the Muslim Brotherhood in general; since 1932, the Muslim Brotherhood had an official section for female affiliates (Zaki, 1980,

\footnotetext{
${ }^{19}$ In many ways, this underlines the importance of posing claims about who supports Islamists in probabilistic terms, i.e. agrarian workers were less likely to support the Brotherhood, rather than completely absent from the movement's supporters.
} 
203-219). To the best of our knowledge, however, there is no systematic information on the social backgrounds of the movement's female supporters. Anecdotally, Mitchell reports that "the number of Muslim Sisters in the university was negligible" and goes on to quote a (male) Muslim Brother's lament that the Muslim Sisters had failed to "attract the educated type $(1993,175)$. Latif $(2008,2)$ speculates that in this early period of the movement, the womens section "consisted mainly of the daughters, wives, and other relatives of the Brothers." We would urge researchers to be alert for opportunities to evaluate these claims.

Second, while the vast majority of signers were literate, the use of stamps suggests that a not insubstantial portion of Egypt's sizable illiterate population was in the Muslim Brotherhood's orbit. In Banha, for example, fully 154 supporters (19 percent) used stamps. We cannot definitively establish whether the factors that drew these men into the movement were systematically different than their literate counterparts — but we suspect that their presence may be a consequence of the Muslim Brotherhood's development in this period. Specifically, towards the end of the 1930s and the beginning of the 1940s, the Brotherhood had begun to expand programs designed to eradicate illiteracy, particularly in poorer urban areas and the countryside (Lia, 1998, 111-112; Mitchell, 1993, 286-289). It seems possible that at least some of these illiterate signatories may have come into contact with the movement through these social service institutions.

Our analysis was possible due to the Muslim Brotherhood's use of petitions. Here, the Brotherhood were following a longstanding repertoire of political dissent in Egypt. As Chalcraft (2005) chronicles, petitions were an established mode of political engagement for both illiterate and literate Egyptians tracing back to the pre-colonial period, which carried over to the British occupation. Here, petitions allowed ordinary subjects located outside of the formal political process to call on state officials to intervene on their behalf (see also Ghalwash 2016). As with other elements of the Brotherhood's mode of mobilizing — such as the formation of scout units, adoption of uniforms, public marches and demonstrations, formal membership and branch structures - the Brotherhood's use of petitions formed part of a pattern whereby early Islamists drew on preexisting 
repertoires of contentious politics that were extra-Islamic in origin (Lia, 1998).

Previous studies have used examples of petitioning to reveal the grievances underpinning nationalist and class-based protest (Brown, 1990b; Cole, 1999). The motivating spirit of the Brotherhood's campaign suggests something different, however. In contrast to painful pocketbook issues or calls for national liberation, the Muslim Brotherhood's petition campaign drew ordinary Egyptians into high-risk activism through abstract feelings of solidarity and community tied to a social movement following the arrest of its leadership. In this, the act of petitioning resembles the regular tours that Brotherhood leaders made to branches located in villages and market towns (Brooke and Ketchley, 2018, 388-391); travels that helped to physically and emotionally connect disparately located outposts of the movement to the Brotherhood's regional hubs and headquarters located in major cities. Here, the circulation and signing of petitions helped the Brotherhood to become a nation-wide movement that spoke with a singular voice. And as we have shown in this paper, through such purposive movement activities, the Muslim Brotherhood was able to attract the support of literate Egyptians, merchants, bureaucrats and professionals at a time when they had limited political opportunities and in a context of unprecedented social transformation. 


\section{References}

Abaza, Mona. 2013. The Cotton Plantation Remembered: An Egyptian Family Story. Oxford University Press.

Abdalla, Ahmed. 2008. The student movement and national politics in Egypt, 1923-1973. American Univ in Cairo Press.

Abdel-Latif, Omayma. 2008. "In The Shadow of the Brothers: The Women of the Egyptian Muslim Brotherhood." Carnegie Papers.

Anderson, Benedict. 2006 (1983). Imagined communities: Reflections on the origin and spread of nationalism. Verso books.

Awaisi, Abdel Fattah Muhammad. 1998. The Muslim Brothers and the Palestine Question, 1928-1947. Tauris Academic Studies.

Ayoob, Mohammed. 2009. The Many Faces of Political Islam: Religion and Politics in the Muslim World. University of Michigan Press.

Ayubi, Nazih. 1991. Political Islam: Religion and Politics in the Arab World. Routledge.

Ayubi, Nazih. 1994. "Over-stating the Arab State.".

Ayubi, Nazih N.M. 1980. "The Political Revival of Islam: The Case of Egypt." International Journal of Middle East Studies 12(4):481-499.

Baer, Gabriel. 1969. Studies in the Social History of Modern Egypt. University of Chicago Press.

Baron, Beth. 2005. Egypt as a woman: nationalism, gender, and politics. Univ of California Press.

Beinin, Joel and Zachary Lockman. 1998. Workers on the Nile: nationalism, communism, Islam, and the Egyptian working class, 1882-1954. American Univ in Cairo Press.

Binder, Leonard. 1978. In a moment of enthusiasm: Political power and the second stratum in Egypt. University of Chicago Press. 
Blattner, E.J. 1937. Le Mondain Egyptien (The Egyptian Who's Who. V. Lubisco \& A. O. Sisto.

Brooke, Steven and Neil Ketchley. 2018. "Social and Institutional Origins of Political Islam." American Political Science Review 112:376-394.

Brown, Nathan. 1990a. "Peasants and notables in Egyptian politics." Middle Eastern Studies 26(2):145-160.

Brown, Nathan J. 1990b. Peasant politics in modern Egypt: the struggle against the state. Yale University Press.

Chalcraft, John. 2005. "Engaging the state: peasants and petitions in Egypt on the eve of colonial rule." International Journal of Middle East Studies 37(3):303-325.

Chalcraft, John T. 2004. The striking cabbies of Cairo and other stories: crafts and guilds in Egypt, 1863-1914. SUNY Press.

Cole, Juan Ricardo. 1999. Colonialism and revolution in the Middle East: social and cultural origins of Egypt's' Urabi movement. American Univ in Cairo Press.

Davis, Eric. 1984. Ideology, social class and Islamic radicalism in modern Egypt. In From nationalism to revolutionary Islam, ed. Said Amir Arjomand. Springer pp. 134-157.

Fischer, Michael M.J. 1982. "Islam and the Revolt of the Petit Bourgeoisie." Daedalus 111(1):101-125.

Fogg, Kevin W. 2019. Indonesia's Islamic Revolution. Cambridge University Press.

Foreign Office. 1932. "F.O. 1/88/32: Political Situation.” British Archives.

Foreign Office. 1942. 'F.O. 141/838 Islamic Societies: Appendix 'A' to Security Summary No. 103. The Ikhwan al-Muslimin Reconsidered. An Appreciation of its Present and Future Significance." British Archives.

George, Alexander L. and Andrew Bennett. 2005. Case studies and theory development in the social sciences. MIT Press. 
Gerring, John. 2004. "What is a case study and what is it good for?" American Political Science Review 98(2):341-354.

Gershoni, Israel. 1986. "The Muslim Brothers and the Arab Revolt in Palestine, 1936-39." Middle Eastern Studies 22(3):367-397.

Gershoni, Israel and James Jankowski. 2009. Confronting Fascism in Egypt: Dictatorship versus Democracy in the 1930s. Stanford University Press.

Ghalwash, Maha A. 2016. "On Justice: Peasants, Petitions and the State in Mid-NineteenthCentury Egypt." British Journal of Middle Eastern Studies 43(4):523-540.

Hafez, Mohammed M. 2003. Why Muslims rebel: Repression and resistance in the Islamic world. Lynne Rienner Publishers.

Hartnett, Allison and Mohamed Saleh. 2021. "Intra-Elite Conflict and the Demand for Democratization: Evidence from Khedival Egypt.” Working Paper.

Heyworth-Dunne, James. 1950. Religious and Political Trends in Modern Egypt. Self-Published. Jankowski, James P. 1975. Egypt's Young Rebels: Young Egypt, 1933-1952. Hoover Institution Press.

Kalmbach, Hilary. 2020. Islamic Knowledge and the Making of Modern Egypt. Cambridge University Press.

Ketchley, Neil and Michael Biggs. 2017. "The Educational Contexts of Islamist Activism: Elite Students and Religious Institutions in Egypt." Mobilization 22(1):57-76.

Khalid, Adeeb. 1999. The politics of Muslim cultural reform: Jadidism in Central Asia. Vol. 27 Univ of California Press.

Kupferschmidt, Uri M. 1982. "The Muslim Brothers and the Egyptian Village." Asian and African Studies 16(1):157-170.

Leckie, George, William Browne, Harvey Goldstein, Juan Merlo and Peter Austin. 2019. "Variance partitioning in multilevel models for count data." arXiv preprint arXiv:1911.06888 
Lia, Brynjar. 1998. The Society of the Muslim Brothers in Egypt: The Rise of an Islamic Mass Movement, 1928-1942. Ithaca Press.

Lia, Brynjar. 2015. “Autobiography or Fiction? Hasan al-Banna's Memoirs Revisited.” Journal of Arabic and Islamic Studies 15:199-226.

Masoud, Tarek. 2014. Counting Islam: Religion, Class, and Elections in Egypt. Cambridge University Press.

McAdam, Doug. 1986. "Recruitment to High-Risk Activism: The Case of Freedom Summer." American Journal of Sociology 92(1):64-90.

Minault, Gail. 1982. The Khilafat Movement: Religious Symbolism and Political Mobilization in India. Columbia University Press.

Mitchell, Richard. 1993. The Society of the Muslim Brothers. Second ed. Oxford University Press.

Mitchell, Timothy. 2002. Rule of Experts: Egypt, Techno-Politics, Modernity. University of California Press.

Moaddel, Mansoor. 2005. Islamic Modernism, Nationalism, and Fundamentalism: Episode and Discourse. University of Chicago Press.

Munson, Ziad. 2001. "Islamic Mobilization: Social Movement Theory and The Egyptian Muslim Brotherhood." The Sociological Quarterly 42(4):487-510.

Noer, Deliar. 1973. The Modernist Muslim Movement in Indonesia, 1900-1942. Oxford University Press.

Reetz, Dietrich. 2006. Islam in the Public Sphere: Religious Groups in India, 1900-1947. Oxford University Press.

Shiraishi, Takashi. 1990. An Age in Motion: Popular Radicalism in Java, 1912-1926. Cornell University Press.

Sidel, John T. 2021. Republicanism, Communism, Islam: Cosmopolitan Origins of Revolutions in Southeast Asia. Cornell University Press. 
Subhi, Muhammad Khalil. 1939. Tarikh al-Hayat al-Niyabiyya fi Misr: Min 'Ahd Rukn al-Jinan Muhammad Ali Basha (al-Juz' al-Sadis). Dar al-Kutub al-Misriyya.

Survey of Egypt. 1932. Index to Place Names Appearing on the Normal 1:100,000 Scale Map Series of Egypt. Government Press.

Survey of Egypt. 1945. "Benha (86/630)." Reprint of Second Edition of Survey of Egypt Map, 1945, by the 42nd Survey Engineer's Regiment, September 1953.

Tripp, Charles. 1984. Ali Mahir Pasha and the Palace in Egyptian Politics, 1936-42: Seeking Mass Enthusiasm for Autocracy. Unpublished PhD thesis, School of Oriental and African Studies

Wendell, Charles. 1978. Five Tracts of Hasan Al-Banna (1906-1949). A Selection from the Majmu at Rasa'il al-Imam al-Shahid Hasan Al-Banna'. University of California Press.

Wickham, Carrie R. 2002. Mobilizing Islam: Religion, Activism and Social Change in Egypt. Columbia University Press.

Wickham, Carrie Rosefsky. 2013. The Muslim Brotherhood: Evolution of an Islamist Movement. Princeton University Press.

Wiktorowicz, Quintan. 2004. Islamic Activism: A Social Movement Theory Approach. Indiana University Press.

Zaki, Muhammad Shawqi. 1980. Al-Ikhwan al-Muslimun wa-l-Mujtama‘ al-Misri [The Muslim Brotherhood and Egyptian Society]. Dar al-Tawzi‘ wa-l-Nashr al-Islamiyya. 